Villa-Caro, Raúl

Carral, Juan Carlos

Fraguela, José Ángel

López, Mario

Carral, Luis

http://dx.doi.org/10.21278/brod69108

ISSN 0007-215X

eISSN 1845-5859

\title{
A REVIEW OF SHIP MOORING SYSTEMS
}

UDC 629.5.028.72: 629.5.028.722

Review paper

\begin{abstract}
Summary
The physical principle that governs how ships are moored to a port has changed little over the years. Nevertheless, in recent decades, there have been developments in maritime transport towards increased vessel dimensions and operations in specialist terminals. These trends mean that offshore ports and mooring systems have to face more challenging conditions in terms of the waves, wind and drift current. At the same time, pier side port loading and unloading systems place demands on the mooring system, which must immobilise ships better. In this situation, the mooring system's own equipment, such as lines, deck fittings and mooring winches, must also evolve to work alongside new port devices. It is also necessary to point out that changes in mooring will take place in subsequent years. These innovations in attaching the ship to the pier will be highlighted here as they mark a significant change in mooring and pier components.
\end{abstract}

Key words: $\quad$ Shipping; Ports; Ship; Mooring; Mooring lines; Mooring winches

\section{Introduction, components and rules}

Whenever a vessel ends its navigation, it goes to a terminal and stops its propulsion, remaining subjected to the action of drifts and winds. At this moment, to be kept safe, it must remain immobilised, fixing its position by means of the elements that make up the mooring system. In this work, the term mooring refers to the system that secures a ship to the terminal. Nevertheless, other solutions are possible, such as mooring to a buoy through single point mooring (SPM), multi-buoy mooring (MBM), floating production storage and offloading vessels (FPSO). Alternatively, ship to ship transfer (SST) may fall under the broad category of mooring, and therefore require specialised fittings or equipment in addition to those for mooring the vessel to the terminal. In any of these cases, an efficient mooring system (Liu et al., 2006; Hsu, 2012; Hsu, 2015) is essential for the safety of the ship, terminal and environment. 
Traditionally the ship mooring system (SSM) has relied on an arrangement of mooring lines that attach the vessel to shore. Also used are on-board fittings, including chocks-fairlead, pedestal rollers and bitt - bollards (Fig. 1). A third consideration is the deck machinery that operates the lines: mooring winches. Over time, novel systems of mooring (NSM) have come into play, by applying alternative physical principles to join the ship to the quay. These provide a glimpse of how current systems will evolve in the future (Villa, 2015).

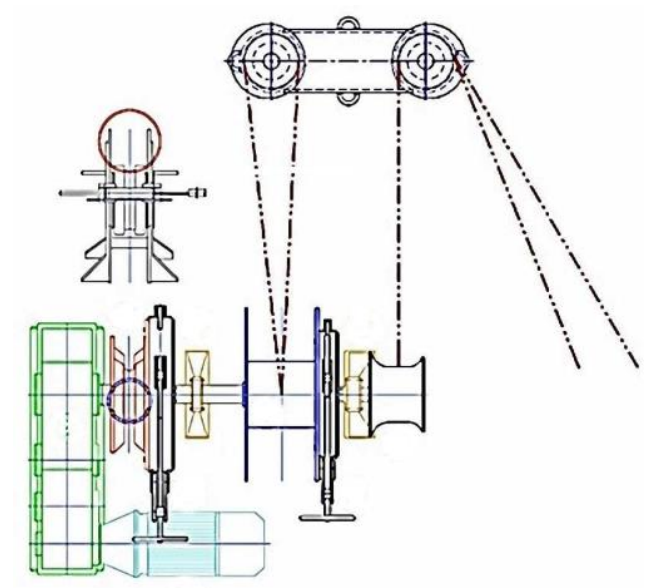

Fig. 1 - Arrangement for mooring manoeuvres with a small electrical windlass to work as a mooring device and a double bitt with a cross-reference function. Source: Carral Design Engineering Solutions.

All of the mooring system's components are determined by vessel type and size, as are other aspects of the project. They are also influenced by regulations applied to each case and by the rules from the classification society chosen by the ship-owner. Nevertheless, Classification Societies (CS) vary significantly in how they deal with the operation and design of mooring system's components (Carral et al., 2015c).

The International Association of Classification Societies (IACS) in part harmonise CS requirements for mooring, anchoring and towing ships in its "Requirements concerning mooring, anchoring and towing" (IACS, 2007a). However, this document only specifies the number of equipment units. The association has not produced a document to harmonise design requirements for the equipment that operates the mooring lines: the mooring winches (Carral et al., 2015c). IACS URA2 - "Shipboard fittings and supporting hull structures associated with towing and mooring on conventional vessels" (IACS, 2007b) has unified CS standards for designing and building mooring fittings.

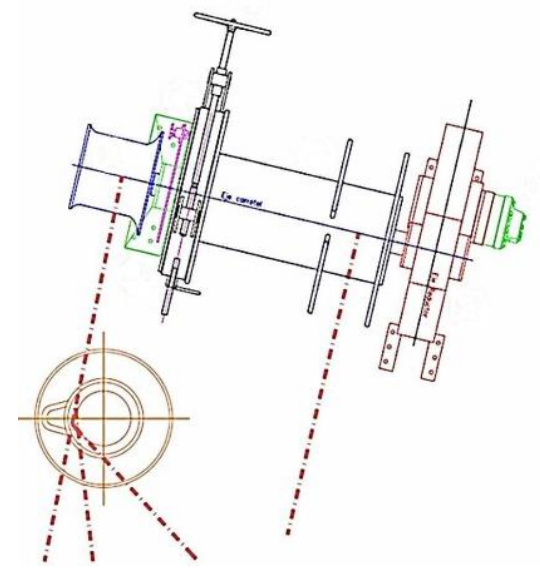

Fig. 2 - Arrangement for mooring manoeuvres that employ constant tension winches with hydraulic operation and cross-referencing. Source: Carral Design Solutions. 
It is up to flag states, governing states of the ports, ship-owners and loaders to create the regulation framework that makes it possible for the ship to operate safely. Inside this framework for ship safety, the states will act in two ways. Firstly, their own regulations, such as ISO or UNE standards, come into play. Moreover, international agreements like the OMI or OIT are also adopted (Carral et al., 2015a). For their part, ship-owners and loaders add a further dimension as they fulfil their own requirements. Among the bodies that establish their own guidelines are the Oil Companies International Marine Forum (OCIMF) and International Gas Terminal Tanker and Operators (SIGTTO). A further influence comes from the rules made by the classification society that ship-owners have selected for their ships. The implementing regulations for mooring systems that come from all these regulatory bodied have been provided in a study (Carral et al., 2015c).

The ISO represents regulatory bodies in more than 156 countries, including many from Europe. It has developed its implementing standards to the case under study through the ISO TC 8 Technical Committee on Shipbuilding and Marine Structures. ISO 3730 (2012) "Shipbuilding - Mooring Winches" for designing and testing the mooring winches cites rules related to winch components and other mooring system elements. All of these are important references in this study.

Currently other, related implementing regulations on deck fittings exist: "Welded Steel bollards and to ropes and cables" (ISO 3913, 1980); "Steel wire ropes" (ISO 2408, 2004); "Fibre ropes" (ISO 1141, 2012); and EN 14687, 14686, 14685, 14684. It is necessary to emphasise that, at the time of publication, there are no national or international standards that specify the minimum strengths for high modulus, synthetic lines.

The Oil Companies International Marine Forum (OCIMF), whose main mission is to promote marine safety by means of responsible development for tankers and terminals, has established in its "Mooring Equipment Guidelines - MEG3", what it takes for mooring systems to be safe (OCIMF, 2008).

\section{Good mooring principles}

A ship's mooring system will always have to resist forces produced by wind, currents and surges from passing vessels (Remery, 1974; Lee, 2015) as well as the effects of waves and swells (Bowers, 1975; Papanikolaou, 1985). At the same time, under all kinds of mooring, it is also necessary to take into account factors like vessel type and size, the characteristics and disposition of its mooring system and terminal and, finally, the physical conditions of the port (Schelfn and Östergaard, 1995).

In the past, the only way to carry out accurate estimates on ship movement and the loads acting on mooring ropes was by performing costly tests with scale models. In recent decades, numerical methods based on simplifications (Table 1) have become available due to increased calculation power. Moreover, it has become possible to develop mathematical models suitable for calculating moored ship motions (Van Oortmerssen, 1976; Seidi et al., 1981; Roberts, 1981; Schellin et al., 1982; Fylling and Andersson, 1988)

Any method for defining design requisites has to envisage how the mooring system is arranged. In other words, it has to take into account the elasticity of the mooring lines and how the moored ship is subject to the action of the wind, currents and forces of the waves. In this way, the designer can choose and position mooring equipment and fittings on board and along the quay. Static calculation methods are used on mooring systems, as proposed by Natarajan and Ganapathy (1995), OCIMF (1994), Aamo and Fossen (2000) and OCIMF (2008). 
Design is informed by the factors of wind action, so that one considers changes in intensity and the longitudinal or transverse angle of incidence. Maximum current is also important: the effect of the ship's draught interacting with under keel water clearance (OCIMF, 2008). In any case, by taking into account the effect due to wind and maximum current, as indicated in Schelfn and Östergaard, (1995), one can also deal with other factors.

Aerodynamic studies will have to be reviewed (OCIMF, 1994; OCIMF 2008; Paulauskas et al., 2009). From the results obtained in wind tunnels for different types of ships, it will be possible to determine the application coefficients in every case studied.

Table 1 - Predictions made using these mathematical models and their general, underlying assumptions. Source:

author's own, based on Schelfn and Östergaard (1995).

\begin{tabular}{|l|l|}
\hline 1 & $\begin{array}{l}\text { First-order ship responses at wave frequencies are modelled as linear responses to harmonic waves using } \\
\text { response functions due to waves of unit amplitude (transfer functions) for the six degree of freedom } \\
\text { motions of the ship. Effects of the linearised stiffness of the mooring system can be accounted for. }\end{array}$ \\
\hline 2 & $\begin{array}{l}\text { Low-frequency ship motions in surge, sway and yaw are not affected by first-order ship motions. They are } \\
\text { modelled as responses to wind, current and wave drift forces acting on the moored ship. }\end{array}$ \\
\hline 3 & $\begin{array}{l}\text { To obtain total response, first-order (high-frequency) response is combined with low-frequency response } \\
\text { using an appropriate method. }\end{array}$ \\
\hline 4 & $\begin{array}{l}\text { Dynamic behaviour of mooring lines and fenders does not significantly affect motions of the moored ship. } \\
\text { Consequently, mooring forces are determined from the instantaneous position of the fairleads and from } \\
\text { load-deflection characteristics of mooring lines and fenders. }\end{array}$ \\
\hline
\end{tabular}

From these proposals, a set of rules can be created to represent mooring principles. Table 2 includes the characteristics that must be respected in the mooring lines in terms of angles, materials and length. Table 3 outlines the properties that the mooring arrangement must have to with the different components involved.

Table 2 - Mooring pattern arrangement.

\begin{tabular}{|ll|}
\hline CHARACTERISTIC & LAYOUT \\
\hline Mooring lines & $\begin{array}{l}\text { Symmetry in number and with the lines positioned between sides and hull of forward } \\
\text { and stern. } \\
\text { Orientation perpendicular to the amidships line and positioned as far as possible from } \\
\text { forward and aft. }\end{array}$ \\
Springs & $\begin{array}{l}\text { As parallel as possible to the amidships line. } \\
\text { Head and stern lines }\end{array}$ \\
Angles & $\begin{array}{l}\text { Positioned along forward and aft with the same length as the rest. } \\
\text { Tails }\end{array}$ \\
Material & With steel line, synthetic tails facilitate handling and elasticity. All of the same length. \\
Length & The same material and class. \\
\end{tabular}


Table 3 - Guidelines for shipboard mooring equipment arrangements.

\begin{tabular}{|c|c|}
\hline COMPONENT & PROPERTY \\
\hline Mooring arrangement & Symmetrical, with the possibility of being used equally from every side \\
\hline \multirow[t]{3}{*}{ Areas of manoeuvre } & Placed to fore and aft as far as possible from mid-section \\
\hline & $\begin{array}{l}\text { Fairleads as far and low as possibleSprings placed at the ends of fore } \\
\text { and aft from the cylindrical body }\end{array}$ \\
\hline & Breast lines placed at the ends of the ship to prevent yawing \\
\hline Winches & $\begin{array}{l}\text { Suitable position for manoeuvre, with and equal line lengths up to the } \\
\text { chocks and bollards }\end{array}$ \\
\hline Mooring areas & $\begin{array}{l}\text { Spaces free for the manoeuvre, which can be clearly seen from this } \\
\text { area. Perfectly aligned lines that runs from the winches, bitt and } \\
\text { fairlead on the side }\end{array}$ \\
\hline Spares & Provide additional bits and fairleads \\
\hline
\end{tabular}

\section{Mooring analyses}

The ship and its mooring system constitute an integrated system that share a dynamic response to environmental loads. However, a mooring system designed to counteract wind and tidal stream action could also do so with wave forces. This is supported by the fact that the static analysis method is frequently sufficient for determining how many mooring lines are needed (Schelfn and Östergaard, 1995). For instance, the OCIMF has met these design conditions at many port terminals worldwide (OCIMF, 2008). Nonetheless, when waves are the dominant action, to carry out a static analysis makes no sense and a dynamic analysis is needed instead (Nakajima et al., 1982; Natarajan and Ganapathy, 1995).

Over recent decades, there have been two trends in sea transport. On the one hand, vessels have grown in size, while the offshore terminals built in deeper waters to accommodate them are more exposed to swells (Paulauskas et al., 2009; Stopford, 2009). On the other hand, large ship motions along the horizontal plane - that is, surge, sway, and yaw can occur at sheltered ports in the absence of higher waves (Shiraishi et al., 1999). The latter is related to resonant processes associated with low-frequency waves, also known as infragravity or long waves. The infragravity waves have periods in the order of minutes and, therefore, can match the natural periods of moored ships and/or harbours (Kubo et al., 2001; Sakakibara et al., 2001; González-Marco et al., 2008; Kwak and Pyun., 2013; López et al., 2012). Large ship motions induced by both swell and long waves can hinder cargo handling and ship mooring operations, break mooring lines or even damage fenders and quay walls as a result of the impact on the vessel.

On these grounds, the efficiency of a mooring system should be assessed in terms of its ability to restrain ship motions (Shiraishi et al., 1999). Moreover, it is important for motion criteria to be suitably defined by considering port requirements or the reference values for safe working conditions found in literature on different vessels and port operations (Elzinga et al., 1992; López and Iglesias, 2014). Nonetheless, defining how a moored ship will respond to wave action is not a straightforward task. This can be explained by dynamic coupling with the mooring system and the nonlinearities associated with resonant processes (Low and Langley, 2008). 
As a first step in analysing the performance of a mooring system, the wave conditions at berth should be determined (Van der Molen and Moes, 2009; Sakakibara and Kubo, 2008a). With this aim, pressure or acoustic sensors can be deployed in the area of interest to obtain the time series of surface elevation. Alternatively, wave propagation numerical models can be used with an accurate description of the harbour and the corresponding bathymetry as inputs. However, numerical approaches should offer the possibility of reproducing phenomena such as diffraction, refraction and reflection, as well as nonlinearities associated with resonance and long waves (Van der Molen and Wenneker, 2008). The most common models involve solving Boussinesq equations (Dong et al., 2013), elliptic mild-slope equations (Bellotti, 2007) or nonlinear shallow water equations (Van Vledder and Zijlema, 2014). Recently, new techniques based on artificial intelligence have also been proposed to estimate wave conditions at berth (López et al. 2015).

Once wave loads have been defined, the interaction of the ship with the incident waves is evaluated by considering the effects of the mooring system. This can be achieved with both numerical and physical models. Thanks to the improved performance of computers and recent theoretical advances in the field, numerical models have gained force in recent years (Sasa and Incecik, 2014). Nonetheless, physical models are still deemed one of the most reliable tools in studying the behaviour of moored ships in harbours; they are needed to calibrate or/and validate numerical models (Pessoa et al., 2015; Rosa-Santos et al., 2014).

Other methods are still under development. However, the most advanced numerical techniques solve ship-wave interactions with a two stage procedure based on potential flow theory (Hirdaris et al., 2014). First, hydrodynamic coefficients are calculated by means of linear frequency-domain methods, known as panel models (Lee and Newman, 2005). The second step involves simulating the behaviour of the moored ship in the time domain frame by applying the impulse response technique (Cummins, 1962). At this stage, the external forces due to the mooring lines and fenders can be introduced into the dynamic system (Kwak and Pyun, 2013).

Stiffness, friction and damping parameters can be used to model the compression action of the fenders. However, if reference values are unavailable, friction and damping will be neglected (Pessoa et al., 2015). Fender systems must withstand large loads during berthing. These loads have commonly been calculated with deterministic methods. More recent and sophisticated methodologies include: statistical procedures (Ueda et al., 2001), the Quick Fender Selection Method (Das et al., 2015) or the finite element method (FEM) (Jiang and $\mathrm{Gu}, 2010)$.

The traditional methodology for analysing mooring lines is done separately from the ship motion analysis. This approach calculates vessel motions using simplified representations or scalar coefficients of the mooring lines. The vessel motions then serve as inputs for the FEM; each line in the mooring arrangement can be analysed in isolation and different materials can be explored. However, this methodology presents several shortcomings, especially when underwater elements and deep water conditions are involved (Ormberg and Larsen, 1998). More advanced methods simulate the behaviour of both the mooring lines and vessel in the time domain. These interconnected methods have been developed for the offshore industry (Chen et al., 2006; Girón et al., 2014; Low and Langley, 2008; Yang et al., 2012). 


\section{Mooring equipment}

\subsection{Mooring lines}

Taking the action of forces produced on the ship as a starting point, the mooring system distributes the forces along the mooring lines. These forces are transmitted to the fixed elements of the terminal. The effectiveness of each will depend on the vertical and horizontal angles that make up the mooring line and that will have to present the lowest possible value (OCIMF, 2008)

The elasticity of a mooring line will depend on factors like the material, as well as its diameter and length. For this reason, between two mooring lines that present different flexible capacity and undergo identical working conditions, the one with the highest diameter and shortest length will, in the end, be subjected to the greatest effort (Schelfn and Östergaard, 1995).

Material is a crucial decision considering the extreme environmental conditions that the ship has to withstand when safe mooring is carried out (OCIMF, 2008; Aamo and Fossen, 2000). A load value will be obtained for this mooring rope: SWL (safe working load). With the corresponding safety factor (SF) playing a role, the MBL (minimum breaking load) can be determined (Table 4). At this point it is necessary to take into account the material to be used for the mooring rope and therefore define the appropriate rope diameter (OCIMF, 2008). Moreover, the material will influence the diameter of the winch drum and the space needed for the manoeuvre, in addition to the type and curvature radius of the chocks, Panama-type fairlead, pedestal rollers and fairleads (Schelfn and Östergaard, 1995).

Low stretch ropes are made of steel cables or synthetic materials, like high modulus polyethylene (HMPE). Using this second option has many advantages and is therefore ideal for larger sized vessels in which high loads are involved. It is also extremely suitable for restricting the ship's motions, in small ports of limited size and loading and unloading operations with those connections. Another area in which HMPE performs well is ones in which high dynamic loads appear (OCIMF, 2008). Its advantages and specific features have been studied in (OCIMF, 2008; Crump et al., 2008; Pederson et al., 2011; Carral et al., 2015b; Carral et al., 2016).

Table 4 - Strength criteria for steel, polyamide and other synthetic mooring lines. Source: author's own, based on OCIMF (2008).

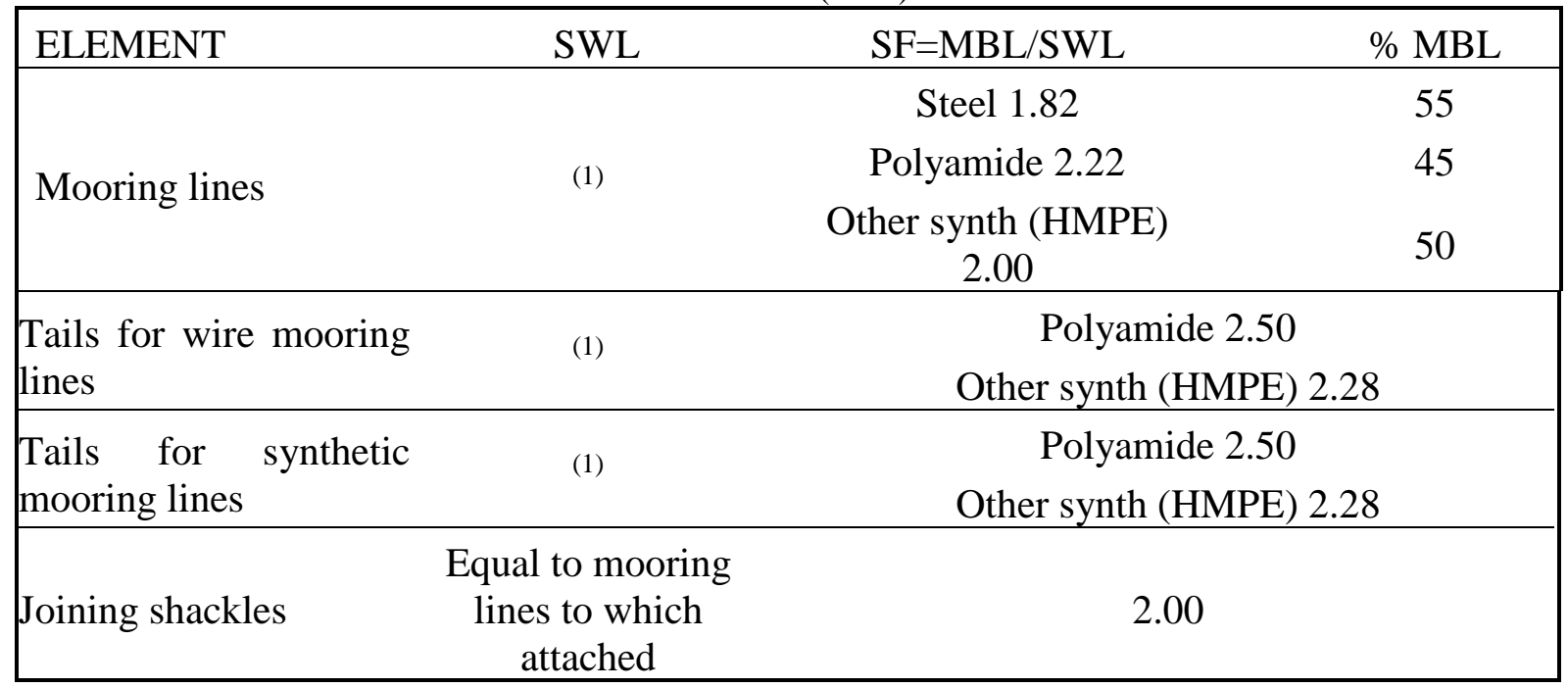

(1) Highest load calculated for adopted standard environmental criteria 
On the other hand, synthetic lines with high elasticity will be used in smaller sized ships where the presence of loads of lower value means that other criteria come to the fore. Among these criteria are ease of use, lower cost and the interchangeability with other lines (OCIMF, 2008)

The steel line and HMPE (low stretch ropes) ones usually have at their ends a small length of synthetic rope, called a pennant or tail. These have many positive points. Tails provide elasticity to the line, are easier for dock crew to handle and make it possible to connect with the bollard and thus protect the main material from abrasion. Their use and the way they are attached to the main mooring rope have been studied in Carral et al. (2016) and Schelfn and Östergaard (1995)

\subsection{Mooring winches}

In the mooring manoeuvre, winches play a vital role. They have to fulfil a dual purpose: handling the mooring lines during the manoeuvre and, after that, keeping them in a suitable place when the ship is in port. The mooring system of the ship has to be adapted when its displacement is altered, or in response to changes in tide or current conditions. The manoeuvre can be done by means of continuous manual adjustments to every rope, or automatically with constant tension winches.

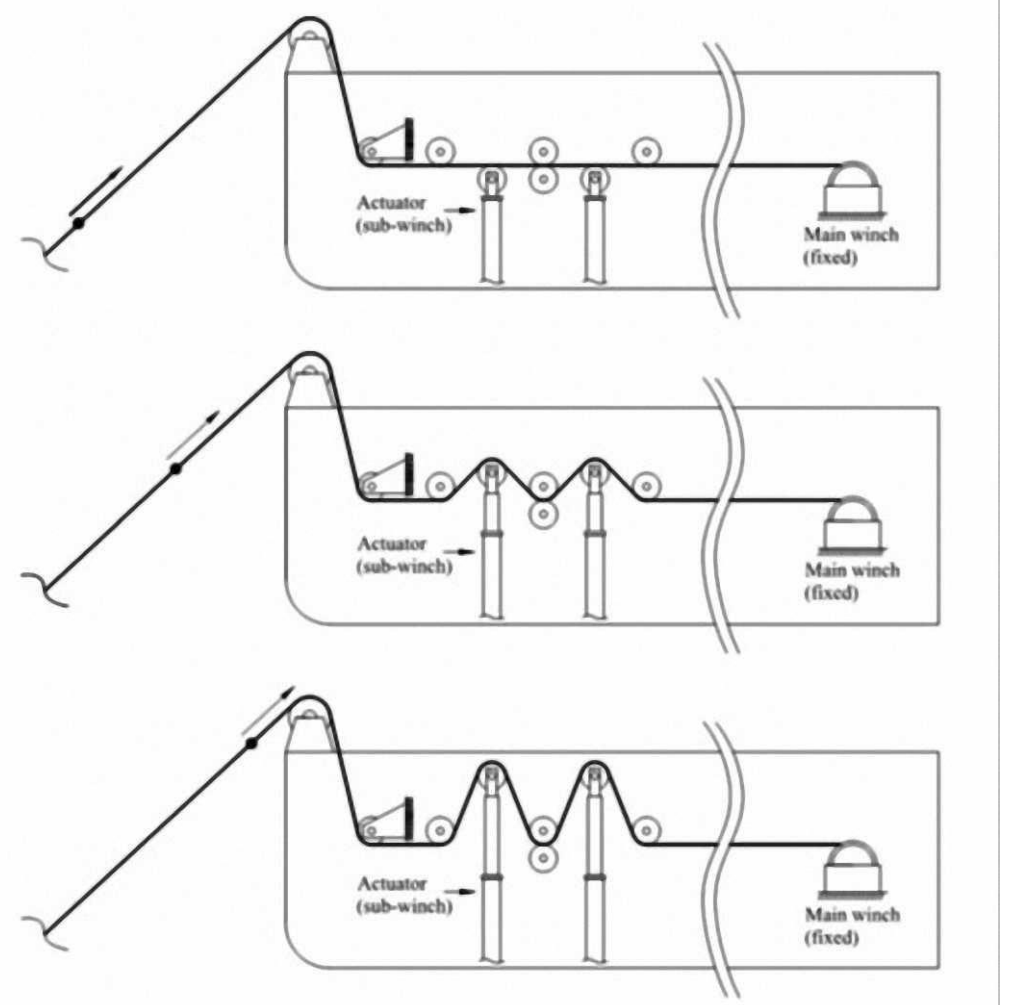

Fig. 3. Vessel motion control strategy using cable tension control with the actuators. Source: Ji et al. (2015).

In contrast with conventional winches, constant tension winches automatically maintain the tension of the mooring line, in a preset value (Table 5). If during the operation the line exceeds a certain value, its drum turns in order to render more line. When the tension decreases, the line is recovered and a fixed tension is reached. Table 5 is based on the content of ISO 3730 (2012). It describes the mooring functions of both conventional or constant tension winches (Lee et al., 2000; Kim, 2014; Carral et al., 2015c; Carral et al., 2015d; Ji et al., 2015) (Fig. 3 and Fig. 4). 
Table 5 - Mooring functions of winches in accordance with ISO 3730 (2012). Source: Carral et al. (2015c)

\begin{tabular}{|c|c|c|}
\hline OPERATION & Conventional mooring winches & $\begin{array}{c}\text { Automatic, constant tension } \\
\text { mooring winches }\end{array}$ \\
\hline Mooring & \multicolumn{2}{|c|}{ By means of drum } \\
\hline Mooring line stowage & \multicolumn{2}{|c|}{ In drum } \\
\hline Tension maintained with brake & \multicolumn{2}{|c|}{ In drum } \\
\hline Mooring line work & \multicolumn{2}{|c|}{ Optional, by means of drum } \\
\hline $\begin{array}{l}\text { Tension maintained through } \\
\text { automatic device }\end{array}$ & Not available & In drum \\
\hline
\end{tabular}

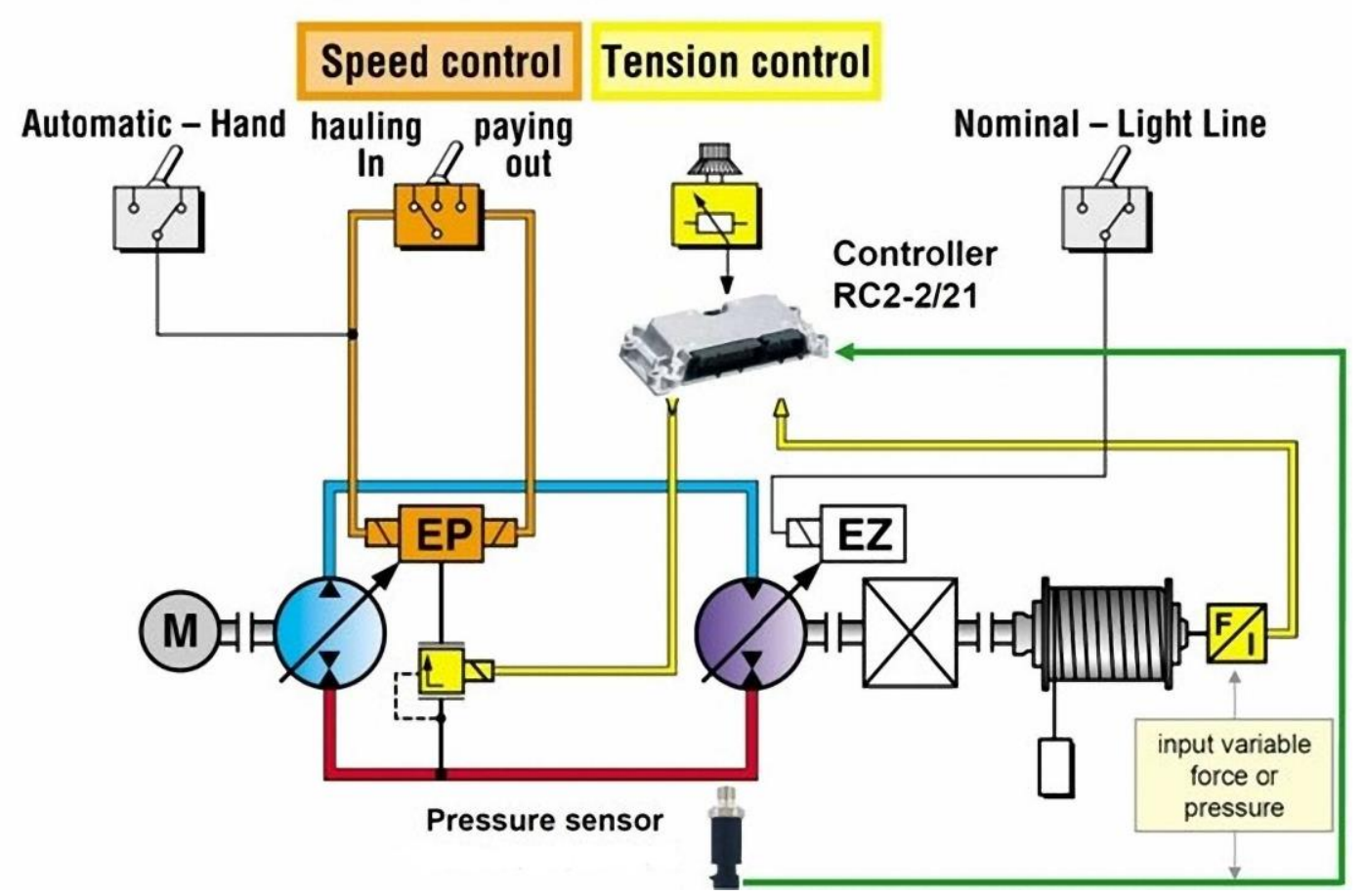

Fig. 4 - Block diagram with the tension control of hydraulically operated mooring winches.

Hydraulic power uses pressure to work the winch, a simple way to control the tension on the mooring line. By means of the pressure sensor, there is a pressure change in the fluid that circulates between the pump and the hydraulic engine. This change corresponds in a linear manner with another in the traction force that the equipment exerts on the mooring line. Source: author's own

\subsubsection{Operation}

The two most common power systems for mooring winches are electrical and hydraulic (Fig. 5 and 6). Hydraulic engines withstand a wide range of speed changes so that a constant torque is maintained. These engines may be slow and have radial pistons or work at a higher speed and have axial pistons. The pistons in the former are commonly used with direct transmission, while those in the latter are coupled by means of a differential (Carral et al., 2015c). 


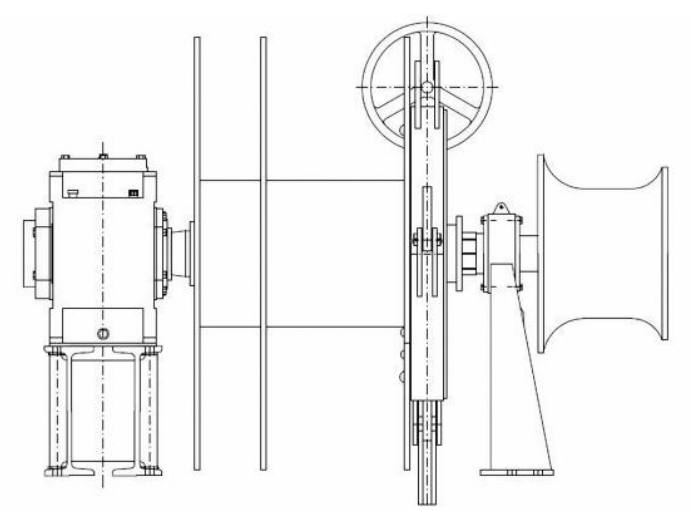

Fig. 5 - Electrically operated mooring winches with differential. Source: Carral Design Engineering Solutions

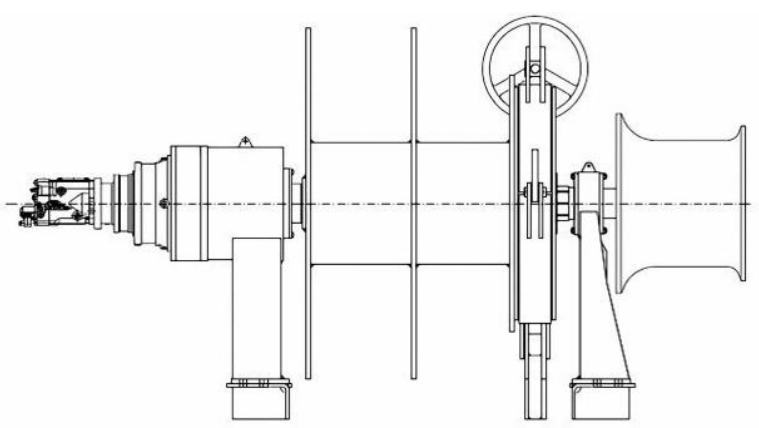

Fig. 6 - Hydraulically operated mooring winches. Source: Carral Design Engineering Solutions

Alternating current engines are more economical, easy to install and of low maintenance. However, they always have to be installed along with a differential. When less power is needed, the economic option is asynchronous, alternating current squirrel cage rotary engines with four poles. When larger engines are needed, a more suitable choice is one with six or eight poles. The choice depends on the cost of combining differential and electrical power. Whenever a constant speed is required, then it is necessary to use hydraulic transmissions with a variable flow pump and possibly variable engine, electrical engines with frequency converter (Carral et al., 2015c) or permanent magnet engines (Lamas et al., 2016). However, one disadvantage remains: the lower efficiency of hydraulic power (Fig. 7, Table 11).
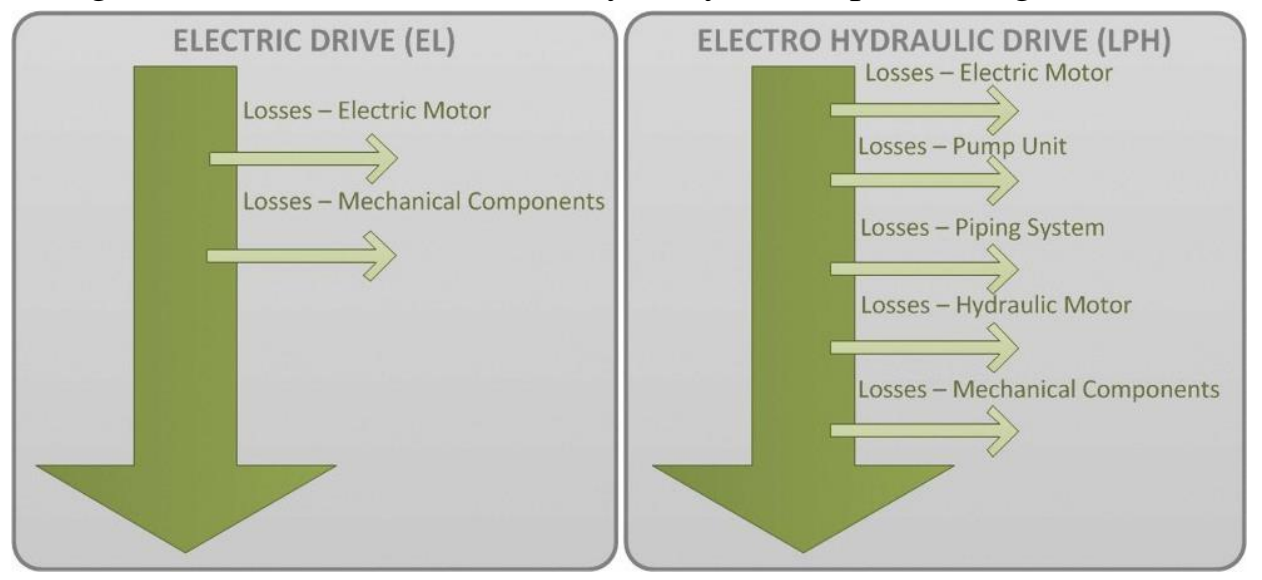

Fig. 7 - Sankey diagram about two forms of power: Electro Hydraulic Drive (LPH) in contrast with Electric

Drive (HE). Source: Lamas et al. (2016)

The data that are necessary for defining the winch are provided in the reference (Table 6) (Carral et al., 2013), and these include the type of work that the winch will carry out, traction, and the rope length it needs to stow. 
Table 6 - Design parameter values for the mooring winches in accordance with different regulations.

\begin{tabular}{|lllll|}
\hline \multirow{2}{*}{ COMPONENT } & ELEMENT / & & & \\
& PARAMETER & SSCC & ISO 3730 & OCIMF (MEG 3) \\
& ROPE DRUM & - & Capacity geometry & Capacity geometry \\
Components & WARPING END & - & ISO 6482 (1980) & - \\
& & To withstand 0.8 & & \\
& & MBL & & Nominal, max \\
& TRACTION & $0.24-0.33$ MBL & Nominal, max, & min, \\
Technical & SPEED & - & - & Withstands 0.8 \\
characteristics & BRAKING & Withstands 0.8 & Withstands 0.8 & MBL \\
& & MBL & MBL & $\begin{array}{l}\text { Max, } \\
\text { DRUM }\end{array}$ \\
& EMERGENCY STOP & - & Max, min, diameter lines \\
\hline \multirow{2}{*}{$\begin{array}{l}\text { Control and } \\
\text { SAFETY }\end{array}$} & PROTECTION & - & Yes & - \\
& SPEED & - & Yes & - \\
\hline
\end{tabular}

Other data are sometimes provided to supplement basic information: type of engine desired for the operation, diameter of the end to be used, render and recovery speeds, braking capacity, the dimensions and type of drum and, lastly, the type of differential.

This procedure first involves knowing the traction or nominal pull. With these data it is possible to consider the material. The value for the rope diameter and the nominal speed can be obtained from the contents in ISO and MEG 3 (ISO, 2012; OCIMF, 2008). This information in turn (Carral et al., 2016) lets one determine the dimensions for the warping end and drum, the type of power and reduction ratio, the power of the winches and the brake's dimensions.

\subsubsection{Dimensions of the drum}

The ideal drum will meet the basic requirement of storing the entire length of cable or rope that is envisaged. It also fulfils the following conditions (Carral et al., 2015c): the mooring rope is not damaged on being coiled, the linear speed of the rendered and recovered cable is kept constant, and that (drum) which in accordance with the drum size, the final dimensions of the mooring winch are reduced).

Complying with these three conditions simultaneously is impossible. It will therefore be necessary to establish a priority list. To minimise the losses that the mooring rope incurs during operation, drums have to be made with cores of a large diameter. On the other hand, if the aim is for the mooring rope to obtain a constant linear speed, it will have to be wound in only one layer. This will make it necessary to produce very wide drums and will affect the dimensions of the winches (Carral et al., 2015c).

ISO and MEG 3 (ISO, 2012; OCIMF 2008) distinguish between two types of drums: single and split. In the first type, the entire rope is reeled into a single chamber, so that the load and linear speed vary from layer to layer (Fig. 8). In the second type, the drum is split 
into a load or working space and another one for stowage by means of an intermediate element. In the load space, the rope is reeled into one layer, so that a constant speed and load are maintained (Fig. 9).

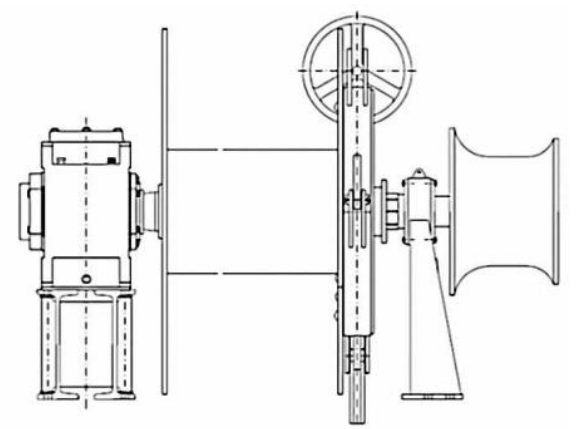

Fig. 8 - Mooring winches with reel. Source: Carral Design Engineering Solutions.
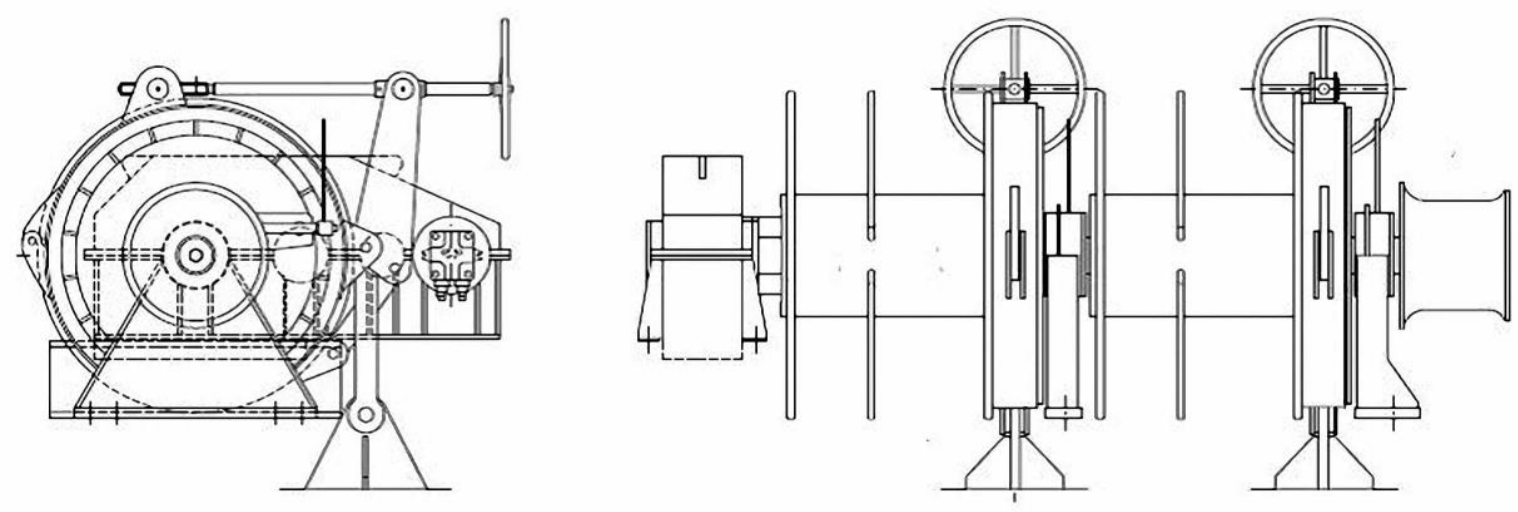

Fig. 9 - Split drum mooring winches. Source: Carral Design Engineering Solutions.

\subsection{Ship fittings}

The document IACS URA2 - "Shipboard fittings and supporting hull structures associated with towing and mooring on conventional vessels" (IACS, 2007b) standardises guidelines for designing and manufacturing the deck components of mooring systems, as indicated below: "fittings and supporting structures used for the normal towing and mooring operations. Shipboard fittings mean those components limited to the following: bollards and bitts, fairleads, stand rollers, chocks used for the normal mooring of the vessel and the similar components used for the normal towing of the vessel".

ISO 3913 (1980) contains standards for mooring bitts (double bollards). In the case of fairleads, bend radius values of 10:1 are recommended for the Panama fairleads. As for the elements that withstand an elevated friction force, a bend radius value of 12:1 is advisable. A similar situation occurs with pedestal rollers, which have a bend radius value of 10:1 and a deflection no higher than $90^{\circ}$ (Schelfn and Östergaard, 1995; Villa, 2015).

\subsection{Fenders}

Fenders are devices used to prevent damage in vessels and/or berth structures with a dual function: (i) to absorb the impact energy during berthing and (ii) to reduce vessel motions during unloading operations by acting with a suitable line arrangement. Each combination of vessel, berth structure and berthing conditions has its own requirements. Ship 
size, berthing method, location, tidal range and water depth are among some of the factors that can influence which fender is chosen (Gaythwaite, 2004).

When fenders are chosen, the basic parameter is the ratio between the force to be withstood by the berth structure and the energy to be absorbed by the fender, which is known as the fender factor. In general, an ideal fender absorbs a large amount of energy and transmits a low reactive load to the berth structure. In other words, it has a low fender factor (Liu and Burchart, 1999). However, with surface-protection fenders and other cases, a high fender factor is advantageous (PIANC, 2002).

The fender factor depends on the material, shape, dimensions and design of the fender. Several materials, such as wood, used tires and rubber cylinders, were commonly used in the past and are still used for small vessels. However, these solutions cannot satisfy the current requirements for large modern ships (Das et al., 2014). State of the art fenders are made of rubber and polyurethane elastomers with excellent elastic properties and can be manufactured with repeatability (Galor, 2007).

Even though a vast variety of fender types are found on the current market, modern systems can be classified into two groups: bucking and pneumatic fenders (Das et al., 2014). This division is according to how they absorb or dissipate kinetic energy from the ships. The former can deflect considerably under loading and return to their original shape after unloading, transforming kinetic energy into elastic work. Some fenders of this group are in direct contact with the ship, while others are equipped with a frontal panel that increases the contact area. As for pneumatic fenders, the pressure of the air confined in bags increases above its normal value by transforming kinetic energy into compression work. A representation of several types of current fenders is shown in Fig. 10.

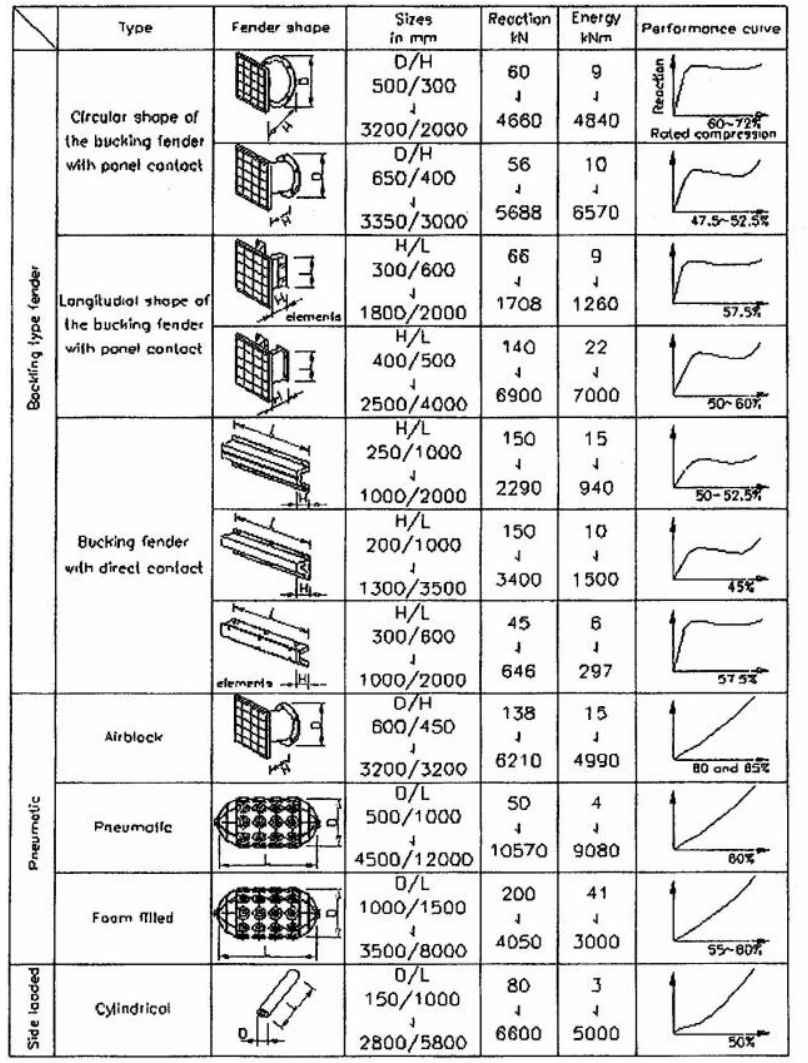

Table 3.1 Different types of energy absorbing elastic deformation rubber units.

13 Report of Working Group 33 - MARCOM

Fig. 10. Different types of fenders. Source: PIANC (2002). 
The reference document for fender system design is the report of Working Group 33 of PIANC (PIANC, 2002). This group suggests the procedure presented in the flow chart from Fig. 11. In addition to a detailed fender design procedure informed by statistical analysis (Ueda et al., 2002), the document provides further relevant information on whole life considerations and special cases, among other topics of interest. Different national guidelines for the design of port facilities are based on PIANC (2002) and provide further information and criteria especially relevant to port engineers and planners (e.g. AS 4997, 2005; BS 63494, 2014; MLIT, 2009; UFC 4-152-01, 2005; ROM 2.0-11, 2012). In the particular case of floating pneumatic fenders, international standards are also available (ISO 17357, 2014).

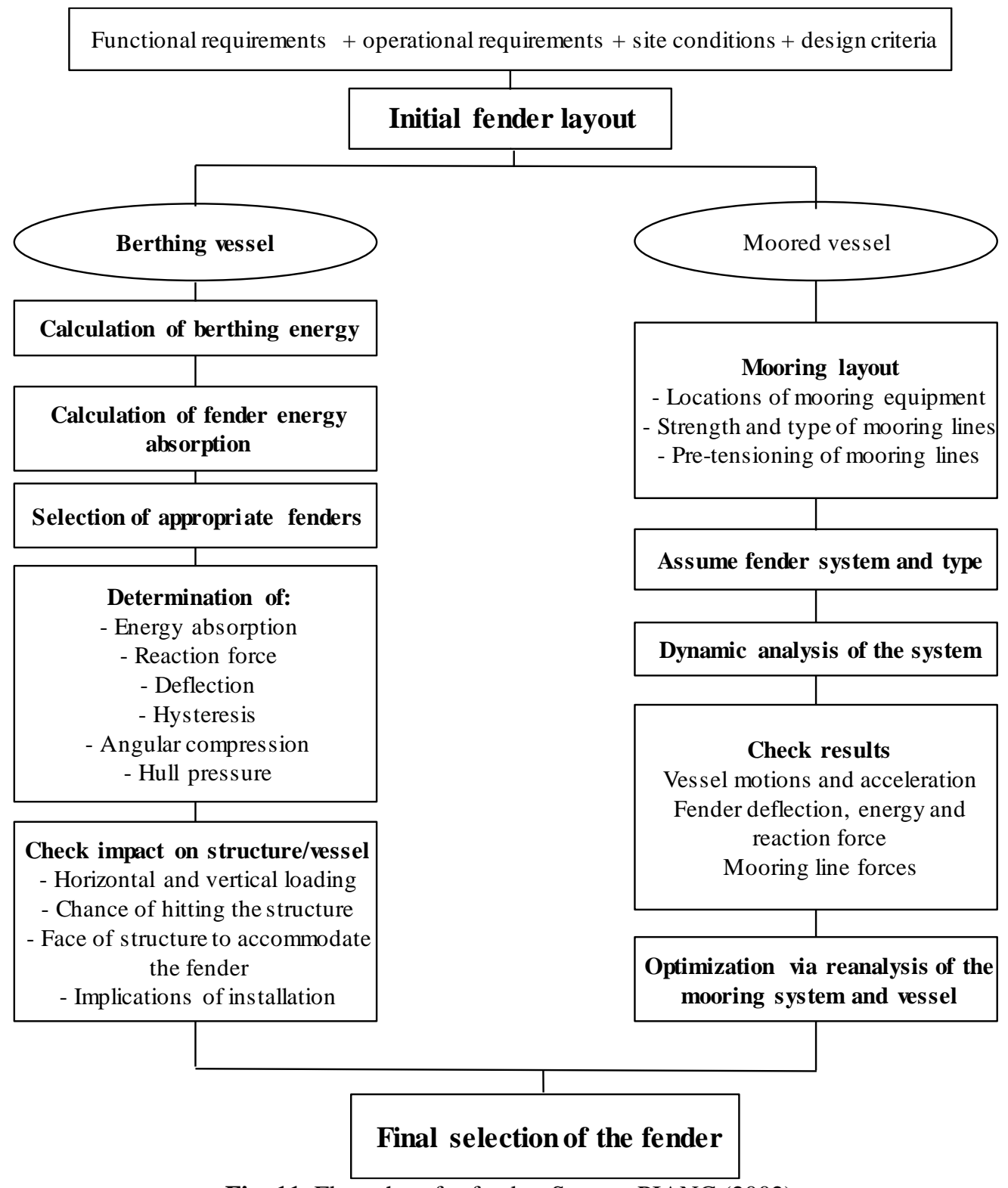

Fig. 11. Flow chart for fender. Source: PIANC (2002).

To simplify the design procedure, a Quick Fender Selection Method (QFSM) was proposed by Das et al. (2014), who obtained a "Ship-fender matrix" derived from application of QFSM to various ships in a terminal of Cochin Port (India). The method was also applied to the design of a safe mooring arrangement for Very Large Crude Carrier (VLCC) in a marine oil terminal (Das et al., 2015).

During port operations, damage to fenders may have a serious impact on mooring facilities or berthing ships. Therefore, in the design stage, finite element methods (FEM) can 
be applied to model their complex material constitutive relationships and deformations. These methods can also define their crash responses with accuracy (Jiang and Gu, 2010). As a countermeasure to possible failures or damage, Sakakibara and Kubo (2007) proposed a monitoring system to check the loads on pneumatic-type fenders on site and alert to several critical conditions. The system can be extended to other types of fenders and port operations, such as ship-to-ship transfer operations and side-by-side moored ships.

\section{Evolution of mooring systems}

\subsection{Mooring system/arrangement modification}

In general terms, problems with berth operability associated with excessive ship motions can be mitigated in two different ways: by reducing wave action on ships or by modifying the ship mooring system's response. The first group includes 'hard solutions' involving changes in the port infrastructures. These may entail: reducing the wave reflection coefficient of the target berth (Uzaki et al., 2010); reducing the wave penetration by extending breakwaters (McComb et al., 2009) or reducing resonance by modifying the harbour layout (Bellotti, 2007). The second group are seen as 'soft solutions' that, by modifying the mooring system, can be an effective and low-cost countermeasure (Sakakibara and Kubo, 2008a).

As mentioned in Section 3, there are no general rules for defining the most suitable mooring system. Each particular case study requires a joint dynamic analysis of the berthed ship and its mooring system. Nonetheless, several studies analysed the mooring arrangement of different vessel types in ports all around the world. They proposed different solutions to improve operation safety and reduce downtimes. The main results of these works are summarised below.

Van der Molen et al. (2006) studied the response of a coal carrier to long waves in Tomakomai Port (Japan) through numerical modelling techniques. They found that the pretension of the lines is a very important parameter. This can be varied to avoid resonance with long waves by shifting the natural period of the mooring system from the predominant period of waves. Therefore, varying mooring line pre-tension can be a good solution for reducing the motions of moored ships in the presence of low-frequency oscillations. On the other hand, smaller motions are the result of increasing the pre-tension value, but line loads also increase.

By means of field observations and numerical modelling, Sakakibara and Kubo (2008a) investigated the excessive motions of a coal carrier in stormy weather. They proposed a mooring system with new characteristics to escape from the resonance between the natural periods of the moored ship and those of the long waves in the port basin. The solution involved modifying the mooring lines and fenders along with adding new mooring dolphins at the ship's bow and stern. It resulted in an effective countermeasure to restrain the low frequency motions of the ship.

In another work, Sakakibara and Kubo (2008b) evaluated the motions of moored oil tankers. They defined an 'asymmetrical parameter' as the ratio of spring constants between fenders and mooring lines and observed that the parameter clearly influences the subharmonic motions of the ships. Moreover, they found that harbour tranquillity can be enhanced when asymmetrical mooring systems are changed to symmetrical or weak asymmetrical ones. To achieve this, pneumatic type fenders were used to great effect.

Yoneyama et al. (2009) presented an alternative that reduces low-frequency surge ship motions of a moored ship by preventing resonance with long waves. The method uses computer-controlled hybrid mooring winches to forcibly change the natural period of the mooring system. The effectiveness of this solution has been checked with field demonstration experiments in Japanes ports. 
In Ahuja et al. (2010a) and Ahuja et al. (2010b), a downtime assessment related to the Dahej LNG terminal in India is presented and the need for the construction of a breakwater discussed. After several studies, including numerical observations and field observations, the original idea of constructing the breakwater to improve downtime was discarded. As safety measures, the number of mooring lines was increased and constant tension, shore-based winches were used to establish safety measures for reducing the downtime for the ships at berth.

Rosa Santos et al. (2014) analysed different mooring arrangements to reduce moored ship motions and to improve operational and safety conditions at berth in the Leixões oil terminal (Portugal). The results of wave tank experiments showed that high friction fenders can increase tension mooring efficiency and reduce a moored ship's motions, especially in the vicinity of the system's natural periods of oscillation. However, varying the magnitude of pretension forces or the type of ship-fender interface makes a limited contribution to reducing moored ship motions under extreme conditions.

De Bont et al. (2010) carried out field measurements and numerical simulations at the Port of Shalah (Oman) to analyse the reduction in surge motions of moored containerships by MoorMasterTM units, a system composed of vacuum pads and hydraulics to secure and control the response of moored ships at berth developed by Cavotec (see next section). They found that MoorMaster ${ }^{\mathrm{TM}}$ units had a reducing affect on surge motions of moored ships. However, several parameters were not measured in the study and the results were not conclusive. More recently, Van der Molen et al. (2015) investigated alternatives to the mooring configuration of bulk carriers in Geraldton Harbour (Australia), including the deployment of twelve MoorMaster ${ }^{\mathrm{TM}}$ units. Although vacuum paddles reduced vessel motions, these motions exceeded the thresholds for maximum excursions of the arms for one of the analysed conditions. According to the results, the highest reduction in vessel motions can be obtained by installing a combination of pneumatic fenders and constant tension winches or nylon breast lines.

Finally, an innovative hydraulic mooring system called ShoreTension ${ }^{\mathrm{TM}}$ has been developed by the mooring company at the port of Rotterdam (KRVE, 2016). This system is situated on the quay side in between two bollards and automatically keeps mooring cables tense in severe conditions. While one end is fixed to the quay bollard, the ship line is connected to the moveable part of the system and a second quay bollard is used for guiding the ship line (Fig. 12). The system was simulated with a dynamic analysis for a generalised Liquid Natural Gas (LNG) terminal under combined wind and wave conditions. Results showed that the motions of the moored vessel and the loads on mooring lines are significantly decreased with ShoreTension ${ }^{\mathrm{TM}}$ (Van der Burg, 2010).

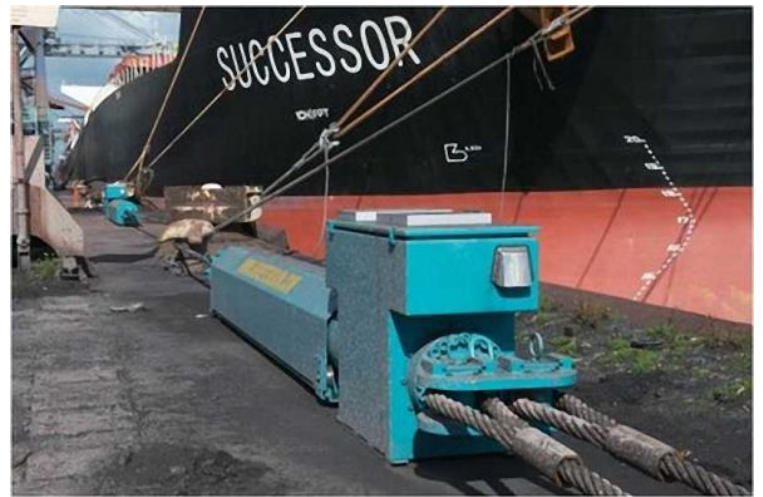

Fig. 12 - Hydraulic mooring system. Source: KRVE (2016) 


\subsection{Novel mooring systems. Classification in accordance with physical principle used.}

For thousands of years, the traditional mooring system with ropes remained unchanged. Nevertheless, changes are currently taking place, having a profound impact on basic mooring principles. These changes challenge time-honoured, traditional and recognised mooring system with ropes.

At present, novel mooring systems (NMS) present two options: a vacuum system and mooring by means of a mechanical arm. Undoubtedly the mooring principle of the first one turns out to be more innovative. At the same time, it is more practical for having eliminated the need to modify the side of the ship. Moreover, it provides greater flexibility to the alignment between ground devices and the ship (Table 7) (Villa, 2015; Villa, 2014).

In 1999, a mooring system called IronSailor was installed for the first time, the work of Mooring Systems Limited (MSL) (Villa, 2015). It was used on the Aretere, a 150-metre-long ferry built by HJ Barreras in Vigo (Spain). The automatic mooring system comprised four 20 tonne units, placed in pairs. There were two units at the bow of the ship and another two at the stern. Activated from the control bridge, the units would open up to attach themselves to a steel plate on the wharf (Fig. 13).

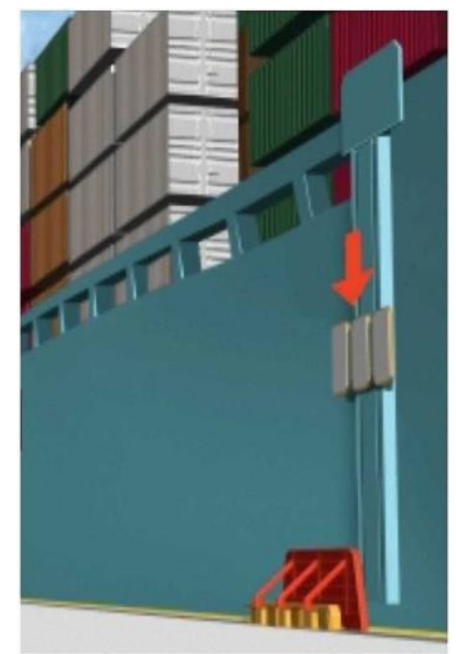

Fig. 13 - Iron Sailor device. Source: Cavotec.

Currently specific facilities are no longer required on a ship; the devices found along the quays can be attached directly to the sides of most ships (Fig. 14). The fact that its storage is retractable when it is not in use is a major advantage. This allows the device to remain behind the fender line to protect itself from impact during docking. When it is activated, the support structure of the device unfolds towards the exterior; mooring connection by vacuum is activated in few seconds (Kim et al., 2014; Cavotec, 2013). This mooring system by means of vacuum was designed to be compatible with most ships. It boasts a range of key characteristics, as indicated in Villa (2015):

- Operates in three directions.

- Accurately positions the ship.

- Manages loads; remote control possible by means of a real-time, computer network that records the information obtained (Villa, 2015). 


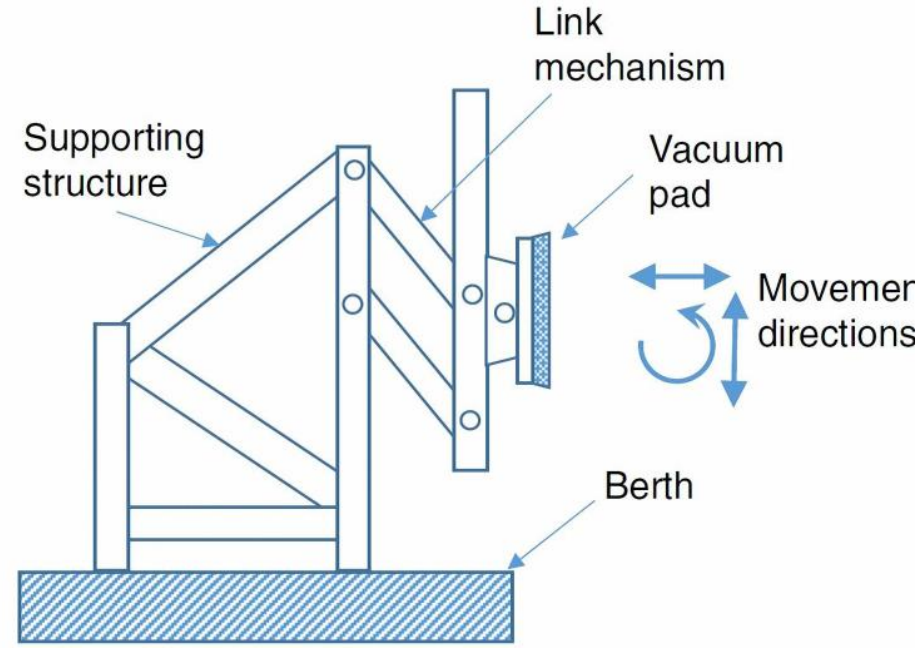

Fig. 14 - Vacuum-operated mooring system deployed along the quay. Source: Cavotec (2013).

Table 7 - Novel mooring system (NMS) with its operational characteristics specified. Source: author's own, based on CAVOTEC (2013) and TTS Group (2016)

\begin{tabular}{|l} 
CARACTERISTICS \\
PRINCIPLE
\end{tabular}




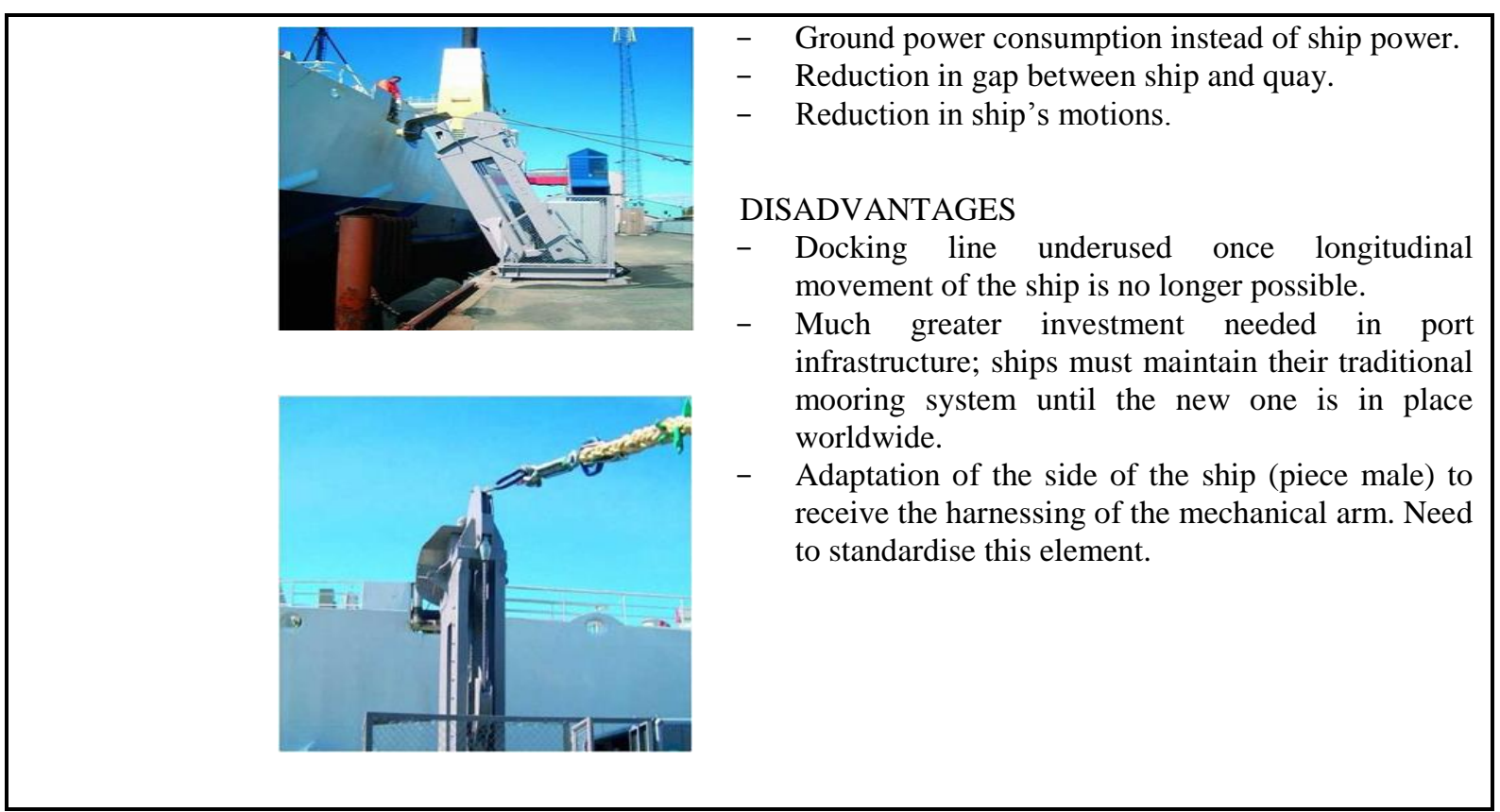

\subsection{Mooring line using HMPE}

To achieve greater efficacy in mooring lines, marine industries have recently adopted high modulus polyethylene (HMPE) as a material. It has great advantages. Among these is its high resistance, similar to that of steel when diameter equality is taken into account. Another benefit is the relationship between resistance and weight, which is superior to that of any other natural or artificial fibre. Moreover, HMPE has low specific gravity so that even line buoyancy is possible (Wardenier, 2011), as seen in Table 8.

Table 8. Comparing the properties of $72 \mathrm{~mm}$ lines of diverse materials. Source: Carral et al. (2016).

\begin{tabular}{|lccccccccc|}
\hline Material & $\begin{array}{l}\text { Diameter } \\
(\mathrm{mm})\end{array}$ & $\begin{array}{l}\text { Weight } \\
(\mathrm{kg} / 100 \mathrm{~m})\end{array}$ & $\begin{array}{l}\mathrm{MBL} \\
\mathrm{k}(\mathrm{kN})\end{array}$ & $\begin{array}{l}\text { Lengthening } \\
\text { to } 40 \% \text { of the }\end{array}$ & $\begin{array}{l}\text { Lengthening to } \\
\mathrm{MBL} \\
\mathrm{MBL}\end{array}$ & $\begin{array}{l}\text { Mof } \\
\text { gravity }\end{array}$ & $\begin{array}{l}\text { Melt. } \\
\text { point } \\
\left({ }^{\circ} \mathrm{C}\right)\end{array}$ & $\begin{array}{l}\text { Dynamic } \\
\text { coefficient of } \\
\text { friction } \\
\text { against metal }\end{array}$ \\
\hline $\begin{array}{l}\text { Polyester } \\
\text { double } \\
\text { braid } \\
\text { Steel }\end{array}$ & 72 & 447.9 & 1054 & $8.5 \%$ & $15-20 \%$ & 1.38 & 250 & $0.12-0.15$ \\
HMPE & 72 & 2200 & 3500 & $0.8 \%$ & $2-3 \%$ & 7.85 & 1600 & 0.23 \\
\hline
\end{tabular}

Table 9. Outstanding properties of HMPE mooring lines. Source: Carral et al. (2016).

\begin{tabular}{|ll|}
\hline Resistance & $\begin{array}{l}\text { Associated with the fibre, independent of the } \\
\text { manufacturer, superiority over other fibres } \\
\text { Weight }\end{array}$ \\
Lengthening & $\begin{array}{l}\text { Lighter than polyester and even more than } \\
\text { steel, buoyancy } \\
\text { Low, which means little capacity for damping }\end{array}$ \\
\hline
\end{tabular}




\begin{tabular}{|c|c|}
\hline & the component dynamics \\
\hline $\begin{array}{l}\text { External and internal } \\
\text { abrasion }\end{array}$ & $\begin{array}{l}\text { Need for external protection (covers) to avoid } \\
\text { friction, which leads to internal abrasion } \\
\text { (warming) }\end{array}$ \\
\hline Fatigue & $\begin{array}{l}\text { Need to act on the cross-reference radius and } \\
\text { rendering devices }\end{array}$ \\
\hline Resistance to heat & $\begin{array}{l}\text { Low, as it is necessary to avoid abrasion, and, } \\
\text { in some cases to cool it }\end{array}$ \\
\hline $\begin{array}{l}\text { Ultraviolet resistance to } \\
\text { beams }\end{array}$ & Need for protective covers \\
\hline Chemical reaction & Attacked by Limnolene \\
\hline
\end{tabular}

With mooring operations in which constant tension is involved, it is necessary to for the drum to keep the line in continuous action. Here the mooring winch plays an active part and, as a result, line wear is a major concern (Carral et al., 2016). Along with all the other properties presented in Tables 8 and 9, a new aspect to take into account is line durability. Crump et al. (2008) have determined that, after 1500 work cycles, the residual resistance of the line end is reduced to $50 \%$ of its initial value in the the tail and $30 \%$ in the middle section of the main line. Therefore, it is recommended that the line is replaced once this number of work cycles has been reached.

With these concerns in mind, operators have designed solutions to extend the line's service life (Crump et al., 2008). The line can be rotated or its end can be cut when it has been severely grazed. Moreover, additional tails can be used at the end of the mooring line in the area withstanding the mechanical action of bits and fairleads. These additional lines could be made of the same material as the main line, or a traditional polyester or polypropylene rope can be used (Wardenier, 2011).

Carral et al. (2016) outline the characteristics common to fairleads used in conjunction with this material. Several factors must be obtained. The fairleads must be manufactured to be robust. They must have the appropriate radius for the line contact surface. Moreover, their surface finish must be of such a high degree of quality that the effect of grazing is minimised (Fig.15). Another key factor is the inalterability of the fairleads' surface over a period of time and in the face of harsh outdoor conditions.

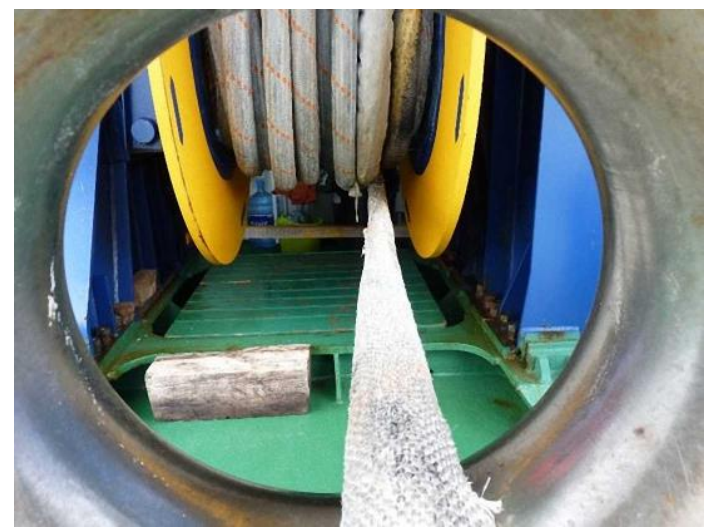

Fig. 15 - Fairlead on vessel, at the tow winch outlet.

\subsection{Operating mooring winches by means of permanent magnet engines}

In industry, permanent magnet engines (PMM) are used when constant torque and high efficiency are important factors for changes in speed. At the same time, these engines are 
being used more in devices like lifts, where a reduced torque, as well as a lower noise and vibration level, are needed. In recent years, they have been perfected to offer a high degree of precision and reliability in applications involving a high transfer torque and low speed. One such case is the mooring winch. This innovative PMM technology in part makes it possible to dispense with reducers in numerous industrial sectors (Ikäheimo, 2002).

When compared with an induction engine of equal power, permanent magnet engines have a notably longer service life. However, their volume is smaller by $47 \%$, resulting in a high torque / volume relationship, and their weight is nearly $36 \%$ lower (Kverneland, 2008). In terms of their efficiency, losses are 15-20\% lower than those caused by induction engines (Munz, 2014). A summary of these advantages can be found in Table 10.

Table 10 - Advantages of PMM. Source: Lamas et al. (2016).

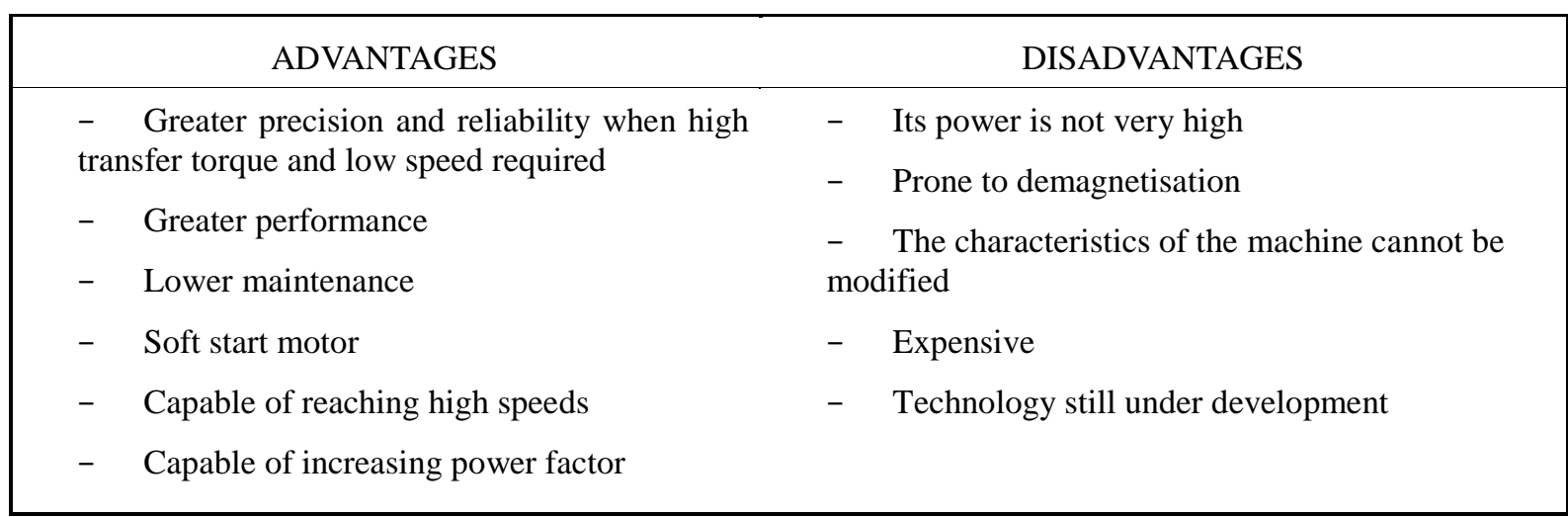

Nevertheless, in the naval sector, the PPM has been, until now, less commonly used, with the exception of a few well-known cases linked to main propulsion (Rojas et al., 2009). Only very recently have they started to be applied to anchor hauling winches and other offshore applications (Vacon, 2016). Lamas et al. (2016) make a strong case for their future application in deck equipment. Table 11 compares this engine with its more conventional counterparts.

Table 11 - Types of winch engines according to the operating mode. Based on Lamas et al. (2016).

\begin{tabular}{|c|c|c|c|}
\hline MODE & HYDRAULIC & $\begin{array}{l}\text { ASYNCHRONOUS } \\
\text { ELECTRICAL }\end{array}$ & ELECTRICAL PMM \\
\hline Motor type & Hydraulic low pressure & Triphasic asynchronous & PMM \\
\hline Mechanic interface & Planetary reducer & Planetary reducer & $\begin{array}{l}\text { Reducer with } 2 / 3 \text { phases or } \\
\text { direct connection }\end{array}$ \\
\hline Control speed and & High control of hydraulic & Mid-level & Elevated \\
\hline torque & flow in power unit & CONTROL SPEED & CONTROL SPEED \\
\hline Performance & $54 \%$ & $70 \%$ & $90 \%$ (expected) \\
\hline $\begin{array}{l}\text { Surges overcapacity } \\
\text { blockage }\end{array}$ & Elevated & Medium & Lower \\
\hline Contamination & Spilled oils & No & No \\
\hline Maintenance & High & Low & Lower \\
\hline
\end{tabular}




\section{CONCLUSIONS}

The term mooring has evolved. What once just referred to the system that secures the ship to the terminal can now also be applied to single point or multi-buoy mooring (MBM), floating production storage (FPSO) and the offloading of vessels or ship to ship transfers. A broader definition of mooring means that specialised fittings or gear is required. Therefore, widespread progress has been made in research and in their application, with the equipment itself and special fittings needed to adapt to these trends.

In this study, proposals have been made in relation to the principles of mooring. In these guidelines, the requirements - including angles, materials and length - of mooring lines were specified. Moreover, the properties required for the various components that make up the mooring system were outlined.

Also important for port operations are studies on reducing ship motions while the vessel is moored but in the presence of waves. These conditions have to be taken into account in the effort to improve the safety of moored vessels, as well as the design and efficiency of the harbour. The forces induced by wave action are compensated by the necessary elasticity of the spring mooring lines, fenders and other devices. Changes in the vessel's elevation are also a concern due to changes in its displacement or tidal range. Line length has to be adjusted so that these changes can be compensated.

Key data for defining mooring winches are provided in Table 6. Other factors are included: the function that it is going to be carried out; tension or pull and the length of mooring rope that must be stored. By determining the tension or nominal pull, along with the physical characteristics of the material, one can obtain the value for the rope diameter and the nominal speed in accordance with ISO and MEG 3 guidelines. With all this information it is also possible to define drum dimensions, operation mode, reduction ratio, the winch power and brake dimensions.

Berth operability issues associated with excessive ship motions can be generally mitigated in two different ways. One is to reduce wave action on ships; the other is to modify the response of the ship's mooring system. The first option involves 'hard solutions' through changes in the port infrastructure. These may entail reducing one of three elements: the wave reflection coefficient of the target berth, wave penetration by extending the breakwaters or resonance by modifying the harbour layout. With the second options, there are 'soft solutions', through a modification of the mooring system. These can be an effective and lowcost countermeasure.

Regarding novel systems of mooring (NMS) two systems come into play: one based on a vacuum and another which employs a mechanical arm. The first is more innovative, yet practical; it eliminates the need to modify the shell side of the ship. Moreover, it facilitates the alignment between the device placed on the wharf and the ship (Table 7).

If HMPE lines are used in the mooring operation based on constant tension, the line is continuously moved by the drum within mooring winches, and this movement leads to line wear. For this reason, certain properties (Table 8 and 9) must be considered, along with the additional concern of line durability.

The last topic explored in this study is related to the use of the permanent magnet motor in marine operations. In recent years, this type of motor has started to be used with anchor handling winches and other offshore applications. Lamas et al. (2016) are confident that the PMM will play an important role in to the operation of deck machinery. 


\section{REFERENCES}

[1] Aamo O., Fossen T. 2000. Finite element modeling of mooring lines, Mathematics and computers in simulation 53, 415 - 422. https://doi.org/10.1016/S0378-4754(00)00235-4.

[2] Ahuja, M.M.; Mani, C.S.; Joshi, A.K (2010a). LNG Berths for Open Seas. Part 1: Dahej LNG Terminal, a Case Study. Port Technol. Int., 46, 125-129.

[3] Ahuja, M.M.; Mani, C.S.; Joshi, A.K (2010b). LNG Berths for Open Seas. Part 2: Dahej LNG Terminal, a Case Study. Port Technol. Int., 46, 125-129.

[4] AS 4997-2005 (2005). Guidelines for the design of maritime structures. Committee CE-030, Maritime Structures. Standards Australia.

[5] Bellotti, G. (2007). Transient response of harbours to long waves under resonance conditions. Coastal Engineering, 54(9), 680-693. https://doi.org/10.1016/j.coastaleng.2007.02.002.

[6] Bowers E., 1975. Long period oscillations for moored techniques of moored ships subjected to short wave seas (transactions, paper w4). The Royal Institution of Naval Architects.

[7] BS 6349-4:2014 (2014). Maritime works. Code of practice for design of fendering and mooring systems. Committee CB/502. British Standards Institution.

[8] Carral Couce J., Carral Couce L., Fraguela Formoso J., Fernández Soto J. 2013. El chigre de remolque en las maniobras de altura y de escolta: propuesta de armonización en sus parámetros de diseño, DYNA Industria y Energía 2013; 88, 395 - 399.

[9] Carral Couce J., Carral Couce L., Fraguela Formoso, J, Villa Caro R., 2015a. Anchor Windlasses, a desing proposal to standardise regulations, International Journal of Maritime Engineering (RINA Transactions Part A).

[10] Carral Couce J., Carral Couce L., Fraguela Formoso, J, 2015b. Diseño armonizado de motones, pastecas y cuadernales para el manejo de lineas de acero o sinteticas de elevado módulo (hmpe) en buques. DYNA - Industria y Energía 2015; 88, 395 - 399

[11] Carral Couce J., Carral Couce L., Fraguela Formoso, J, Villa Caro R., 2015c. Standardising the design and production of mooring winches through more cohesive regulations: a necessary step, International Journal of Maritime Engineering (RINA Transactions Part A).

[12] Carral Couce L., Carral Couce J. C., Fraguela Formoso J., 2015 d, Operation and handling of escort tugboats with the aid of automatic towing winch systems, The Journal of Navigation, 68, 1, 71

[13] Carral Couce L., Fraguela Formoso J., De Troya Calatayud J., Carlos Alvarez Feal, 2016 forthcoming. Influence of the towline material - steel or high modulus polyethylene (HMPE) on towing gear design and tug deck fittings. JEME 2016

[14] Cavotec MSL Holdings Limited (2013) Automated mooring method and mooring system, Patent Registration No. US-8408153

[15] Chen, X., Ding, Y., Zhang, J., Liagre, P., Niedzwecki, J., \& Teigen, P. (2006). Coupled dynamic analysis of a mini TLP: Comparison with measurements. Ocean Engineering, 33(1), 93-117. https://doi.org/10.1016/j.oceaneng.2005.02.013.

[16] Crump T., Volpenhein K., Chou R., (2008), Samson Abrasion and Fibre Fatigue in High Performance, Synthetics for Ship Escort and Berthing -, USA, ITS 2008, Singapore

[17] Cummins, W. E. (1962). The impulse response function and ship motions (No. DTMB-1661). David Taylor Model Basin Washington DC.

[18] Das, S. N., Kulkarni, S., \& Kudale, M. D. (2015). Design of Safe Mooring Arrangement for Large Oil Tankers. Procedia Engineering, 116, 528-534. https://doi.org/10.1016/j.proeng.2015.08.322.

[19] Das, S. N., Kulkarni, S., \& Kudale, M. D. (2015). Design of Safe Mooring Arrangement for Large Oil Tankers. Procedia Engineering, 116, 528-534. https://doi.org/10.1016/j.proeng.2015.08.322.

[20] Das, S.N., Kulkarni, S., Kudale, M.D. (2014). Selection of fender system. International Journal of Scientific Engineering and Technology, 3(Special issue), 27-31.

[21] de Bont, J., van der Molen, W., van der Lem, J., Ligteringen, H., Mühlenstein, D., \& Howie, M. (2010). Calculations of the motions of a ship moored with the Moormaster ${ }^{\mathrm{TM}}$ units.In Proc. of the 32nd PIANC International Navigation Congress, Liverpool, UK, 10-14 May 2010; 622-635.

[22] Dong, G., Gao, J., Ma, X., Wang, G., Ma, Y., 2013. Numerical study of low-frequency waves during harbor resonance. Ocean Eng. 68, 38-46. https://doi.org/10.1016/j.oceaneng.2013.04.020.

[23] Elzinga, T., Iribarren, J. R., Jensen, O. J., 1992. Movements of moored ships in harbours. In: Coastal Engineering Proceedings 1(23). 
[24] Fylling, I. J., Andersson, F., 1988. Simulation of motions of berthed vessels simplified simulation model. In Proc. Advances in Berthing and Mooring of Ships and Offshore Structures, (NATO ASI Series, Series E: Applied Sciences Vol. 146). Kluwer Academic Publ., Dordrecht, The Netherlands, 1988, pp. 298-303. https://doi.org/10.1007/978-94-009-1407-0_12.

[25] Galor, W., 2007. The modelling of buckling fenders to protect the ship berthing process. Journal of KONES, 14, 169-175.

[26] Gaythwaite, J., 2004. Berthing Loads and Fender System Design, in: Gaythwaite, J. (Ed.) Design of Marine Facilities for the Berthing, Mooring, and Repair of Vessels, American Society of Civil Engineers Press, second Edition, pp. 133-176. https://doi.org/10.1061/9780784407264.ch05.

[27] Girón, A.R.C., Corrêa, F.N., Hernández, A.O.V., Jacob, B.P., 2014. An integrated methodology for the design of mooring systems and risers. Mar. Struct. 39, 395-423.

https://doi.org/10.1016/j.marstruc.2014.10.005.

[28] González-Marco, D., Sierra, J. P., de Ybarra, O. F., Sánchez-Arcilla, A., 2008. Implications of long waves in harbor management: The Gijón port case study. Ocean Coastal Manage. 51(2), 180-201. https://doi.org/10.1016/j.ocecoaman.2007.04.001.

[29] Hirdaris, S.E., Bai, W., Dessi, D., Ergin, A., Gu, X., Hermundstad, O. A., ... \& Fonseca, N., 2014. Loads for use in the design of ships and offshore structures. Ocean Eng. 78, 131-174. https://doi.org/10.1016/j.oceaneng.2013.09.012.

[30] Hsu, W.K. (2012). Ports'service attributes for ship navigation safety. Saf. Sci. 50 (2), 244 -252. https://doi.org/10.1016/j.ssci.2011.08.057.

[31] Hsu, W.K. (2015). Assessing the Safety Factors of Ship Berthing Operations. J. Navig. 68, 576 - 588. https://doi.org/10.1017/S0373463314000861.

[32] Ikäheimo, J., 2002. DriveIT Permanent Magnet Motors. www.novec.ru/catalog/novosibirsk/catalog/abb/perm_drv.pdf. (Accessed February 2016).

[33] IACS, 2007a. Requirements concerning mooring, anchoring and towing. International Association of Classification societies (IACS).

[34] IACS, 2007b. Shipboard fittings and supporting hull structures associated with towing and mooring on conventional vessels. International Association of Classification societies (IACS).

[35] ISO 17357, 2014. Ships and marine technology - Floating pneumatic rubber fenders. International Organization for Standardization (ISO).

[36] ISO 2408, 2004, Steel wire ropes. International Organization for Standardization (ISO).

[37] ISO 3913, 1980. Welded Steel bollards and to ropes and cables. International Organization for Standardization (ISO).

[38] ISO 3730, 2012. Shipbuilding - Mooring winches. International Organization for Standardization (ISO).

[39] ISO 6482, 1980. Shipbuilding - Deck machinery - Warping end profiles. International Organization for Standardization (ISO).

[40] ISO 1141, 2012. Fibre ropes. International Organization for Standardization (ISO).

[41] Ji, S.W., Choi, M.S., Kim, Y.B., 2015. A study on position mooring system design for the vessel moored by mooring lines, IEEE-ASME Trans. Mechatron. 20(6), 2824-2831. https://doi.org/10.1109/TMECH.2015.2407612.

[42] Jiang, Z., Gu, M., 2010. Optimization of a fender structure for the crashworthiness design. Materials \& Design, 31(3), 1085-1095. https://doi.org/10.1016/j.matdes.2009.09.047.

[43] Kim, Y.B., 2014. A study on the control system design for ship mooring winch system. Journal of Mechanical Science and Technology, 28(3), 1065-1072. https://doi.org/10.1007/s12206-013-1181-9.

[44] Kim, Y.B., Choi, K.J., Chung, H., Han, S., Lee, P.S., 2014. A ship-to-ship automatic docking system for ocean cargo transfer. J Mar Sci Technol, 19, 360-375. https://doi.org/10.1007/s00773-014-0256-3.

[45] KRVE, 2016. Dynamic-Mooring-System. http://www.shoretension.nl/wpcontent/uploads/ShoreTension\%C2\%AE-Dynamic-Mooring-System.pdf. (Retrieved may 23, 2016).

[46] Kubo, M., Saito, K., Sakakibara, S., Kitano, M., \& Sawada, M. (2001). A study on suitable mooring system for large and small ships under waves and wind. In: Proc. of Coastal Engineering Conference, American Society of Civil Engineers-ASCE, 4, 3629-3642. https://doi.org/10.1061/40549(276)283.

[47] Kverneland, H., 2008. Permanent magnet motors lead way to better power efficiency, safety on cranes, winches. Drilling contractor July- Aaugust 2008, pp. 98 - 101 
[48] Kwak, M., Pyun, C., 2013. Numerical analysis of moored ship motion considering harbor resonance in Pohang New Harbor. In: Proc. of the 7th International Conference on Asian and Pacific Coasts (APAC 2013) Bali, Indonesia, 24 September 2013.

[49] Lamas Pardo M., Carral L., Castro-Santos L., Carral J., 2017. Offshore Anchor Handling winch- drive options. Brodogradnja: journal of naval architecture and shipbuilding industry. Volume 68 , Number 3 , 2017.

[50] Lee D., Kim J., Kim H., 2000. Desing of automatic winch systems for small fishing vessel, Bulletin of Korean society of fisheries technology 36(3), 157-166.

[51] Lee S., 2015. A numerical study on ship-ship interaction in shallow and restricted waterway, Int. J. Nav. Archit. Ocean Eng. 7, 920 - 938. https://doi.org/10.1515/ijnaoe-2015-0064.

[52] Lee, C., Newman, J.N., 2005. Computation of wave effects using the panel method. WIT Transactions on State-of-the-art in Science and Engineering, 18.

[53] Liu, C.P., Liang, G.S., Su, Y., Chu, C.W., 2006. Navigation safety Analysis in Taiwanese ports. J. Navig. 59(2), 201-211. https://doi.org/10.1017/S0373463306003687.

[54] Liu, Z., \& Burcharth, H. F., 1999. Port Engineering. Aalborg Universitet, Inst. for Vand, Jord og Miljøteknik, Laboratoriet for Hydraulik og Havnebygning.

[55] López, M., Iglesias, G., 2014. Long wave effects on a vessel at berth. Appl. Ocean Res. 47, 63-72. https://doi.org/10.1016/j.apor.2014.03.008.

[56] López, M., Iglesias, G., Kobayashi, N., 2012. Long period oscillations and tidal level in the Port of Ferrol. Appl. Ocean Res. 38, 126-134. https://doi.org/10.1016/j.apor.2014.03.008.

[57] López, M., López, I., Iglesias, G., 2015. Hindcasting Long Waves in a Port: An ANN Approach. Coast Eng. J. 1550019. https://doi.org/10.1142/S0578563415500199.

[58] Low, Y.M., Langley, R.S., 2008. A hybrid time/frequency domain approach for efficient coupled analysis of vessel/mooring/riser dynamics. Ocean Eng. 35(5), 433-446.

https://doi.org/10.1016/j.oceaneng.2008.01.001.

[59] McComb, P.J., Johnson, D. L., Beamsley, B. J., 2009. Numerical study of options to reduce swell and long wave penetration at port Geraldton. Coasts and Ports 2009: In a Dynamic Environment, 490.

[60] MLIT, 2009. Technical Standards and Commentaries for Port and Harbour Facilities in Japan. Ports and Harbours Bureau, Ministry of Land, Infrastructure, Transport and Tourism (MLIT). The overseas Coastal Area Development Institute of Japan.

[61] Munz, R., 2014. Popularity of permanent magnet motors is on the rise. http://www.pbsionthenet.net/article/72729/Popularity-of-permanent-magnet-motors-is-on-the-rise.aspx

[62] Nakajima, T., Motora, S., Fujino, M., 1982. On the dynamic analysis of multi- component mooring lines. In: Proceedings of the Fourteenth Offshore Tech nology Conference, pp. 105-110. https://doi.org/10.4043/4309-MS.

[63] Natarajan, R., Ganapathy, C., 1995. Analyses of moorings of a berthed ship. Mar. Struct. 8, 481-489. https://doi.org/10.1016/0951-8339(95)97305-R.

[64] OCIMF, 1994. Prediction of wind and current loads on VLCCs, Oil Companies International Marine Forum, Witherby \& Co. Ltd., London, UK.

[65] OCIMF, 2008. Mooring Equipment Guidelines - MEG3. Oil Companies International Marine Forum.

[66] Ormberg, H., Larsen, K., 1998. Coupled analysis of floater motion and mooring dynamics for a turretmoored ship. Appl. Ocean Res. 20(1), 55-67. https://doi.org/10.1016/S0141-1187(98)00012-1.

[67] Papanikolaou, A., 1985. On the evaluation of motions and loads of arbitrary bodies in waves. In: Proc. Inc. Symp. On Ocean Space Util. 85, Tokyo pp- 75-86.

[68] Paulauskas, V., Paulauskas, D., Wijffels J., 2009. Ship safety en open ports. Transport, 24(2) 113-120. https://doi.org/10.3846/1648-4142.2009.24.113-120.

[69] Pederson, M., Mozsgai, G., Stenvers, D., 2011. The Effect of Bending in the Tensile Strength of Statically Loaded Synthetic Ropes. In: Proc. of the 9th International Rope Technology Workshop, Texas, USA, 22-24 March 2011.

[70] Pessoa, J., Fonseca, N., Soares, C. G., 2015. Numerical study of the coupled motion responses in waves of side-by-side LNG floating systems. Appl. Ocean Res. 51, 350-366.

https://doi.org/10.1016/j.apor.2015.01.012. 
[71] PIANC (2002). Guidelines for the Design of Fenders Systems. Report of Maritime Navigation Commission Working Group 33, Permanent International Association of Navigation Congresses (PIANC).

[72] Remery, G., 1974. Mooring forces induced by passing ships. In Proc. Offshore Technology Conf. (paper No OTC2066) Houston, 1974. https://doi.org/10.4043/2066-MS.

[73] Roberts, J. B., (1981). Non linear analysis of slow drift oscillations of moored vessels in random seas. J. Ship Research, 25(2).

[74] Rojas, D., Sarasquete, A., Rial, D., 2009. Consideraciones sobre la aplicación de motores eléctricos con tecnología de imanes permanentes para el accionamiento directo de maquinaria rotativa en buques. 48 Sesiones Técnicas de Ingeniería Naval - Asociación de Ingenieros Navales de España - AINE, Vigo.

[75] ROM 2.0-11 (2012). ROM 2.0-11. Design and construction of Berthing \& Mooring Structures. Puertos del Estado. (In Spanish).

[76] Rosa-Santos P., Taveira-Pinto F., Veloso-Gomes F., 2014. Experimental evaluation of the tensión effect on the response of moored ships. Coast. Eng. 85, 60-71. https://doi.org/10.1016/j.coastaleng.2013.11.012.

[77] Sakakibara, S., Saito, K., Kubo, M., Shiraishi, S., Nagai, T., Yazaki, F., 2001. A study on long-period moored ship motions in a harbor induced by a resonant large roll motion under long-period waves. In: Proc. of The 11th International Offshore and Polar Engineering Conference. International Society of Offshore and Polar Engineers (ISOPE), Stavanger, Norway, 17-22 June 2001.

[78] Sakakibara, S., Kubo, M., 2007. Ship berthing and mooring monitoring system by pneumatic-type fenders. Ocean Eng. 34(8), 1174-1181. https://doi.org/10.1016/j.oceaneng.2006.07.006.

[79] Sakakibara, S., Kubo, M., 2008a. Characteristics of low-frequency motions of ships moored inside ports and harbors on the basis of field observations. Mar. Struct. 21(2), 196-223. https://doi.org/10.1016/j.marstruc.2007.11.002.

[80] Sakakibara, S., Kubo, M., 2008b. Effect of mooring system on moored ship motions and harbour tranquillity. International Journal of Ocean Systems Management, 1(1), 84-99. https://doi.org/10.1504/IJOSM.2008.017783.

[81] Sasa, K., Incecik, A., 2012. Numerical simulation of anchored ship motions due to wave ans wind forces for enhanced safety in offshore harbor refuge. Ocean Eng. 44, 68-78. https://doi.org/10.1016/j.oceaneng.2011.11.006.

[82] Schelfn, T. E., \& Östergaard, C., 1995. The vessel in port: Mooring problems. Mar. Struct. 8(5), 451-479. https://doi.org/10.1016/0951-8339(95)97304-Q.

[83] Schellin, T. E., Scharrer, M., Matthies, H. G., 1982. Analysis of vessels moored in shallow, unprotecte d waters. In Proc. of the Offshore Technology Conference (OTC 4.243). Houston.

[84] Seidi, L.H., Ishi, B.T., 1981. A system for the analysis of the dynamics of vessels and platforms moored offshore. In: Proc. 3rd Int. Syrup. on Offshore Eng., COPPE, Rio de Janeiro, Brazil,

[85] Shiraishi, S., Kubo, M., Sakakibara, S., Sasa, K., 1999. A study on numerical simulation methods to reproduce long-period ship motions. In Proceedings of the 9th International Offshore and Polar Engineering Conference (ISOPE), Brest, France, 30 May-4 June 1999.

[86] Stopford, M., 2009. Maritime Economics, 3th ed. Oxon: Routledge (2009), p 74 Cap II The organization of the shipping market.

[87] Ueda, S., Hirano, T., Shiraishi, S., Yamamoto, S., Yamase, S., 2002. Statistical design of fender for berthing ship. In: Proc. of The 12th International Offshore and Polar Engineering Conference (ISOPE), Kitakyushu, Japan, May 25-31, 2001

[88] UFC 4-152-01, 2005. Design of Piers and Wharves: Unified Facilities Criteria. US Army Corp of Engineers.

[89] Uzaki, K. I., Matsunaga, N., Nishii, Y., Ikehata, Y., 2010. Cause and countermeasure of long-period oscillations of moored ships and the quantification of surge and heave amplitudes. Ocean Eng. 37(2), 155-163. https://doi.org/10.1016/j.oceaneng.2009.12.004.

[90] Vacon (2016). Advanced winch technology for extracting oil deep under the sea. http://www.vacon.com/es-ES/Vacon/media/References/Advanced-winch-technology-for-extracting-oildeep-under-the-sea/ (accesed february 2016).

[91] Van der Burg, G., 2011. ShoreTension: secured to shore at all times. In: Port Technology International, 52, 43-46.

[92] Van der Molen, W., Moes, H., 2009. General characteristics of South African ports and the safe mooring of ships. SATC 2009. 
[93] Van der Molen, W., Wenneker, I., 2008. Time-domain calculation of moored ship motions in nonlinear waves. Coast. Eng. 55(5), 409-422. https://doi.org/10.1016/j.coastaleng.2008.01.001.

[94] Van der Molen, W., Monardez, P., Van Dongeren, A., 2006. Numerical simulation of long-period waves and ship motions in Tomakomai Port, Japan. Coast Eng. J. 48(1), 59-79. https://doi.org/10.1142/S0578563406001301.

[95] Van der Molen, W., Scott, D., Taylor, D., Elliott, T., 2015. Improvement of Mooring Configurations in Geraldton Harbour. J. Mar. Sci. Eng. 4(1), 3. https://doi.org/10.3390/jmse4010003.

[96] Van Oortmerssen G., (1976). The motions of moored ship in waves, Netherlands ship model basin, Wageningen. The Netherlands, publication $\mathrm{n}^{\mathrm{o}} 510$ pp. 1-138.

[97] Van Vledder, G. P., Zijlema, M., 2014. Non-Hydrostatic Wave modeling in Partly Sheltered Harbor Basins. In: Proc. of ICCE 2014: 34th International Conference on Coastal Engineering, Seoul, Korea, 15 20 June 2014. https://doi.org/10.9753/icce.v34.waves.11.

[98] Villa-Caro R. (2014). Revolución en los sistemas de amarre de los buques, Revista General de Marina num. Abril pp. 475-490.

[99] Villa-Caro R. (2015). Sistemas de amarre en buques: situación actual y evolución futura. RUC Universidade da Coruña.

[100] Yang, M., Teng, B., Ning, D., Shi, Z., 2012. Coupled dynamic analysis for wave interaction with a truss spar and its mooring line/riser system in time domain. Ocean Eng. 39, 72-87. https://doi.org/10.1016/j.oceaneng.2011.11.002.

[101] Yoneyama, H., Asakura, K., Kawasaki, T., Otake, Y., 2009. Development of a reduction system for lowfrequency ship motions and its field experiments by using a large ship. In: Proc. of 19th International Offshore and Polar Engineering Conference, International Society of Offshore and Polar EngineersISOPE. Osaka, Japan, 21-26 June 2009; pp. 1117-1123.

Submitted: 28.02.2017. Raúl Villa-Caro, raul.villa@udc.es, University of A Coruña Juan Carlos Carral, jcarral@icoiig.es; Carral Design Engineering Solutions

Accepted: 28.11.2017. José Ángel Fraguela, jafraguela@udc.es, University of A Coruña Mario López, mario.lopez@uniovi.es, University of Porto (FEUP) Luis Carral, lcarral@udc.es, University of A Coruña 